\title{
Wall paintings through the ages: the medieval period (Italy, twelfth to fifteenth century)
}

\author{
Zuleika Murat $^{1}$ (D)
}

Received: 11 May 2021 / Accepted: 30 June 2021 / Published online: 13 October 2021

(C) The Author(s) 2021

\begin{abstract}
This paper is devoted to wall painting in the Middle Ages (ca. late fifth to early fifteenth centuries), with a focus on twelfth to fifteenth century Italy. It is conceived as a critical conflation of diverse methodologies, approaches and research tools, with the aim of investigating the topic from different and complementary perspectives. Historical textual sources provide the interpretive framework for the examination, which is conducted on specific, yet interrelated aspects. Special attention is paid to technical features, including the methods and materials used to produce wall paintings. Data from scientific investigations are incorporated into the discussion with the purpose of elucidating theoretical conceptualizations with material pieces of evidence. A number of selected case studies is presented within the text in order to keep the focus of analysis on the materiality of the paintings, hence avoiding the formulation of abstract concepts in favour of more pragmatic approaches.
\end{abstract}

Keywords Wall painting $\cdot$ Middle Ages $\cdot$ Medieval painting $\cdot$ Italy $\cdot$ Painting techniques $\cdot$ Pigments

\section{Premise}

This Topical Collection (TC) covers several topics in the field of study, in which ancient architecture art history, archaeology and material analyses intersect. The chosen perspective is that of a multidisciplinary scenario, capable of combining, integrating and solving the research issues raised by the study of mortars, plasters and pigments (Gliozzo et al. 2021).

The first group of contributions explains how mortars have been made and used through the ages (Arizzi and Cultrone 2021, Ergenç et al. 2021, Lancaster 2021, Vitti 2021). An insight into their production, transport and on-site organisation is further provided by DeLaine (2021). Furthermore, several issues concerning the degradation and conservation of mortars and plasters are addressed from

This article is part of the Topical Collection on Mortars, plasters and pigments: Research questions and answers

Zuleika Murat

zuleika.murat@unipd.it

1 Dipartimento dei Beni Culturali: archeologia, storia dell'arte, del cinema e della musica, Università Degli Studi Di Padova, Piazza Capitaniato 7, 35139 Padova, Italy practical and technical standpoints (La Russa and Ruffolo 2021, Caroselli et al. 2021).

The second group of contributions is focused on pigments, starting from a philological essay on terminology (Becker 2021). Three archaeological reviews on prehistoric (Domingo Sanz and Chieli 2021), Roman (Salvadori and Sbrolli 2021) and Medieval (this paper) wall paintings clarify the archaeological and historical/cultural framework. A series of archaeometric reviews illustrate the state of the art of the studies carried out on Fe-based red, yellow and brown ochres (Mastrotheodoros et al. 2021); Cu-based greens and blues (Švarcová et al. 2021); As-based yellows and reds (Gliozzo and Burgio 2021); Pb-based whites, reds, yellows and oranges (Gliozzo and Ionescu 2021); Hg-based red and white (Gliozzo 2021) and organic pigments (Aceto 2021). An overview of the use of inks, pigments and dyes in manuscripts, their scientific examination and analysis protocol (Burgio 2021) as well as an overview of glass-based pigments (Cavallo and Riccardi 2021) are also presented. Furthermore, two papers on cosmetic (Pérez Arantegui 2021) and bioactive (antibacterial) pigments (Knapp et al. 2021) provide insights into the variety and different uses of these materials. 


\section{Introduction}

This paper examines a distinctive use that, in the Middle Ages, artists made of plaster, mortar and pigments. Namely, their combined employment as materials for wall painting, one of the main domains of the period's visual culture. Although wall painting could be used for relatively small projects, such as individual panels dedicated to a single figure, it was more often carried out on huge areas, sometimes - as in the case of the Church of St Francis in Assisi (Umbria region, central Italy)—on entire buildings. This circumstance, together with the fact that wall painting requires rapid execution times, necessitated a rigorous arrangement of the worksite and the work phases, as well as the simultaneous presence of several painters, organised in workshops led by a master. According to surviving documentary evidence, for example, 8 to 29 men worked at the same time on the building site of the Palace of the Popes in Avignon, France, in the period January to October 1336 (Piola Caselli 1981; Zanardi 2002); in the same building, another 21 men were paid alongside Matteo Giovannetti, the workshop's master, for paintings done between 1365 and 1366 (Müntz 1889; Zanardi 2002). From $19^{\text {th }}$ July to $2^{\text {nd }}$ of October 1369,24 men worked on the decoration of two chapels in the Vatican palace (Vatican City, Rome, Italy), designated in documents as 'magistri pictores' (i.e. painters) or generically divided into 'magistri et operarii' (i.e. painters and labourers or apprentices) (Zanardi 2002).

Wall painting techniques were first developed in Antiquity and are evidenced by numerous surviving samples dating back to Roman times, as well as by frequent references in theoretical and technical treatises. The Middle Ages inherited these competences and yet declined them in a way as to meet new criteria, with specific respect to the different use that people made of painted decorations in Christianity, introducing some significant technical and stylistic innovations. Wall painting was used all over Europe, in the Mediterranean basin, in the Balkan territories and in Russia, with techniques and materials that, as we shall see, were substantially similar. In this paper, we will focus mainly on European territories, where the highest percentage of medieval wall paintings survives, and specifically on Italy from the twelfth to the fifteenth century. The chronological focus is determined by the surviving paintings themselves, which are most numerous for the later centuries of the Middle Ages but which nevertheless include samples from earlier periods, that will also be discussed here.

Knowledge of wall painting materials and techniques is progressing rapidly as more paintings are examined scientifically in view of or during restorations, while at the same time new and more accurate diagnostic methods and tools are established. It has become clear that written sources, namely theoretical texts and practical treatises from the period under examination, provide crucial tools to establish a first-hand interpretive framework about the methods and materials of a given era. On the other hand, raw data from scientific examinations are crucial to improve, develop and sometimes rectify the concepts provided by these sources. In this paper, therefore, evidence from scientific and technical examinations will be coupled with theoretical information provided by textual sources. Also, it is now common knowledge that, although within a standard system, techniques and methods could vary even within a single region, sometimes even within the praxis of one artist from work to work. It is therefore necessary to adopt a flexible approach, capable of accounting for possible variations, divergencies and fluctuations.

\section{Medieval sources}

It should be made clear from the outset that by sources we refer here to collections of various kinds relating to the production of wall painting; archival sources associated to individual works will, on the contrary, be left aside, and they will only be mentioned in the text where appropriate. In other words, we are interested in those writings where, even if a systematic exposition is often lacking, the author or assembler is moved by practical purposes and hence provides effective advice or guidance. These anthologies of technical instructions provide crucial insight into medieval workshops and artistic practice. Over 400 treatises and compendia are known, most of them dating from the eighth to the fifteenth century (Viñas 1998; Tosatti 2000b, 2007; Clarke 2001).

Given that the main treatises of Antiquity and the early Christian era, as Theophrastus' Liber de lapidibus (ca. 370-287 BC), Vitruvius' De architectura (end of first century BC), Pliny's Naturalis Historia (23-79 AD) and Dioscorides' De materia medica (end of first century AD), up to the writings of Isidore of Seville (ca. 570-636), were never completely forgotten, we need to consider that medieval treatises often incorporated new theological reflections, that regarded artistic production as a way to praise God and Creation. Sometimes alchemical and medical concepts were also included, especially in relation to the economic, moral, cultural and social values attributed to matter and materials. Also, medieval treatises often consist in compendious texts, which gather, assemble and revise previous works, adding new considerations. In addition to being artists of various kinds, their authors were often clerics and intellectuals. 
Medieval collections belong to different typologies, including so-called recipe books, technical treatises, model books and iconographic and formal repertoires.

\section{Recipe books and practical treatises}

The so-called recipe books and practical treatises constitute one of the main types of medieval artistic treatises, and they are pivotal sources of information for studying medieval artworks, for understanding their character and composition, and for planning rigorous restoration campaigns. The data they provide have been corroborated by diagnostic investigations, which attest precisely to the use of the materials and practices mentioned by these texts.

The text known as Compositiones Variae is among the oldest treatises. It consists of a collection of chemical recipes with instructions on how pigments and dyes should be prepared and used (Hedfords 1932; Johnsons 1939; Caffaro 2003; Burns 2017). The oldest preserved copy is a parchment manuscript written by different hands between the eighth and the ninth century, kept in the Biblioteca Capitolare in Lucca, Tuscany (Cod. 490). It is indeed also referred to as the 'Lucca manuscript', or even as Compositiones ad tingenda, after the title that Muratori, its first publisher, assigned to it (Muratori 1739). The preparation of mineral pigments and organic colourants is extensively illustrated and the treatise also contains the first known recipe for vermilion. In addition, it provides guidance and recipes to prepare gilding and gold inks. A close examination of the linguistic specificities of the text, which is written in poor Latin with traces of Greek origin, together with its contents and terminology, has revealed relations with Assyrian cuneiform tablets of the seventh century BC, passed through the Classical, Greco-Byzantine and Alexandrin alchemistic traditions.

All but 26 recipes of the Compositiones Variae are incorporated into the Mappae Clavicula, itself a compendium of recipes (Roosen-Runge 1967; Smith and Hawthorne 1974; Baroni 2013; Kroustallis 2013; Frison and Brun 2018), possibly composed in France or Germany, and, like the Compositiones, connected to ancient Egyptian and early Greek alchemist knowledge (Halleaux and Meyvaert 1987; Clarke 2013). The text survives in different copies (almost 80 complete manuscripts or fragments from the ninth to the seventeenth century), including some fragments in a late eighth-century bifolium in the Augustiner Chorherrenstiftes Library in Klosterneuburg, Austria, and in a tenth-century codex preserved in the Bibliothèque Humaniste of Sélestat, France (MS. 17). A copy is known to have existed in 821 in the Library of Reichenau Abbey, Germany, one of the leading religious, cultural and artistic centres of the Carolingian age in Europe. The most complete copy of the Mappae Clavicula is contained in a twelfth-century manuscript housed in the Corning Museum of Glass in New York (Phillipps
MS. 3715). The collection was extremely popular throughout the Middle Ages and beyond: most medieval treatises and recipe books drew on it (Johnson 1935, 1937). The text consists of recipes for preparing glues and pigments from minerals, herbs, woods and stones. It also provides descriptions of the nature of chemical products and guidance on working metals.

A decisive trend reversal is represented by the $D e$ coloribus et artibus Romanorum, which manifests already from its title a keen interest in the artistic practice of ancient Rome. In fact, in contrast with previous treatises, it betrays the influence of Roman traditions, techniques and materials, and incorporates elements drawn from the writings of Vitruvius (Raspe 1781; Giry 1878; Richards 1940; RoosenRunge 1967; Garzya Romano 1996; Merryfield 1999). The treatise's author, Eraclius, was either a native of Italy or a northerner who was very well informed on Roman artistic customs. Consequently, the composition of the treatise has been localised in either Italy or northern Europe. The two most complete copies of the De coloribus survive in a German manuscript dated 1250-1300, today housed at the British Library in London (Eegerton LM. 840 a), and in a French manuscript written in 1431 (Paris, Bibliothéque National, MS. Lat. 6741). It is generally agreed, however, that the text was compiled much earlier, at some time between the seventh and the twelfth century. The treatise is subdivided into three books. Books I and II were composed in verse by one hand and they constitute the original text by Eraclius. Book III is instead written in prose by a different author and was added in the twelfth or thirteenth century. It is no surprise, hence, that Book III bears little mention of the arts of the Romans and discusses instead contemporary recipes and techniques, while also repeating some pieces of the information provided in the other chapters. According to Roman praxis and conventions, Books I and II provide in 13 and 7 chapters respectively pigment recipes, instructions for glazing earthenware, advice on the decorative use of glass, guidance on the cutting and polishing of crystal and precious stone, and prescriptions on how to give copper the appearance of gold.

The De diversis artibus is the first known treatise written by an artist. It is indeed the most complete account of the various working methods of medieval artists; it survives in many copies and was used throughout the Middle Ages (Hendrie 1847; Merryfield 1999; Caffaro 2000; Tosatti 2007; Dines 2013; Speer 2014). As the author explains in the preface, he wishes to dedicate his accomplishment and skills to God; uninterested in achieving fame on earth, he signs his work with the pseudonym 'Theophilus, humilis presbyter', i.e. Teophilus, humble priest (Tosatti 2000a; Kroustallis 2014). He has been identified as the Benedictine monk and goldsmith Roger of Helmarshausen since in the prologue of the oldest extant copy of the De diversis artibus 
(Österreichische Nationalbibliothek, Wien, MS. 2527), dated from the early twelfth century, the signature reads 'Theophilus qui et [sic] Rugerus'. This is further substantiated by additional circumstantial pieces of evidence: first, the date and provenance of the earliest manuscripts prove that the text was composed in north-west Germany during the first half of the twelfth century. Roger of Helmarshausen, a native of Germany, is documented as working precisely at that time. Secondly, although the De diversis artibus discusses techniques other than metalworking, yet the largest part of the text is dedicated to metalwork. Roger was precisely an expert in that medium. This theory, formulated by Ilg (1874) and contested by Degering (1928), has been resumed and reaffirmed on the basis of new analyses of the text (Freise 1981, 1985; Davis-Weyer 1994) and is now generally accepted within the scholarly community. While the consistency of the treatise is undisputed, the structure of the text and its modifications over the centuries are instead quite problematic. In fact, the original text, which was already complex and articulated, has undergone additions and transcription errors-common issues for medieval manuscripts. In addition to being a practitioner in the arts, the author is also a learned collationist of ancient sources-including Pliny, Isidore of Seville, Raban Maurus (ca. 784-856) and Eraclius (Dodwell 1961). Yet, the main core of the text gives first-hand practical advice and instructions. Book I deals with painting techniques, including panel and wall painting, and illumination, with specific attention being paid to colour application. The author begins by describing the way colour is applied to paint faces, nudes and clothing (Zanardi 1995). He then prescribes to trace thick outlines, typically found in Romanesque painting indeed, and to use various hues of colour to emphasise shadows and light, creating the illusion of volume and depth. Theophilus then moves on to the composition of compound pigments, describing some recipes for a selected sample of colour such as cinnabar.

The Romanesque De coloribus et mixtionibus (Thompson Jr. 1933; Bulatkin 1954; Tosatti 2007), which advocates the application of colour according to a tripartite schemebasic tone, darker outline, lighter shade-has perhaps not yet received the attention it deserves (Thompson Jr. 1933; Bulatkin 1954; Tosatti 2007). This conventional rendering of the colour scale according to triplets of shades, for the purposes of volumetric articulation, is perhaps the main stylistic and technical characteristic of late medieval and early Renaissance art, and is found not only in later treatises, but also in numerous paintings of the period (Tosatti 2000).

The first artistic treatise in the vernacular, an authoritative text that marks the transition from fourteenth-century tradition to early Renaissance culture, is Cennino Cennini's Libro dell'arte (Cennini 2012; Cennini 2015). Cennino was a painter. His father Andrea was also probably a painter. Cennino began his career in Florence, Tuscany, as an apprentice of Agnolo Gaddi, son and pupil of Taddeo Gaddi, who had been taught by Giotto. In other words, Cennino descends directly in line from Giotto and represents the third generation of painters trained in the Giottesque tradition - a fact he proudly emphasised. He is mentioned in only two documents, both dated 1398, where he is said to be a painter living in Padua (Veneto region, northern Italy). No signed or documented works by him have survived, although attempts have been made to assign him a few paintings (Boskovits 1973; Biotti 2018).

Cennino's Il libro dell'arte was written ca. 1390 (Tosatti 1993). It is believed to have been produced in Padua, as it is dedicated to St Antony of Padua and in addition contains many Venetian terms (Ricotta 2019). The original text does not survive, but three later complete copies exist. The earliest one is dated 31 July 1437 and was compiled in Florence, where it is still preserved (Biblioteca MediceaLaurenziana, MS. 23.P.78). The second one is also kept in Florence (Biblioteca Riccardiana, MS. 2190), and probably dates from the second half of the sixteenth century. It is thought to be the most true-to-the original version (Torresi 2004). The third copy is much later (Rome, Biblioteca Apostolica Vaticana, MS. Ottob. 2974), as it was probably made in the eighteenth century. The text was highly influential and was used throughout the late Middle Ages and the Renaissance. Although bound to medieval culture in its structure as a handbook of artistic techniques-from panel and wall painting (the main focus is on fresco), to painting on canvas, illumination and goldsmithing-nonetheless the treatise anticipates notions of art which were only conceptualised during the Renaissance. Cennino identifies Giotto as the initiator of an unprecedented artistic revolution, against the background of a new, elevated social status of the artist, who is seen as equal to intellectuals and philosophers by the use he makes of 'fantasia e hoperazione di mano', i.e. the ability 'to discover unseen things hiding under the shadow of nature and to fix them with the hand, demonstrating what does not actually exist' (Bolland 1996). Cennino then proceeds urging painters to emulate poets, giving free rein to their imagination and creativity. In this context, a special attention is paid to drawing, considered as a fundamental step to exercise and improve the artist's skills but also as a way to enhance creativity (Procacci 1977). Indeed, Cennino describes carefully the various drawing materials available to the artist and the preparation of drawing supports such as parchment, tracing paper and tinted paper. As compared to late medieval historical and technical treatises, the Libro dell'arte is the first entirely first-hand practical manual to have survived, and it constitutes a fundamental source for the knowledge of late medieval painting techniques and workshop's praxis. In earlier treatises, in fact, the occurrence of precepts derived from previous sources is common. Cennino on the other hand, provides first-hand recipes. He describes in detail the 
methods for producing pigments and the time needed for their manufacturing. He also illustrates their specific properties and their appropriateness for manuscript illumination, panel painting and wall painting. In addition, he gives recipes for manufacturing other materials such as gesso, glues and mordants which were to be used to produce painting, and provides advice on the various techniques to apply the layers of gesso and bole. Cennino is also interested in how to create a 'cangiante' (shot) drapery, to simulate a richly patterned brocade and to achieve a variety of decorative effects by using gold and metal leaves (Eclercy 2007), pastiglia (i.e., modelled or cast gesso to produce pattern in relief), punching and tooling. As we shall see, the soundness and effective nature of Cennino's detailed instructions have been proved during technical examinations of numerous fourteenth- and fifteenth-century paintings.

Finally, it is worth mentioning the collection of artistic writings and pigment recipes known as Tabula de vocabulis sinonimis et equivocis colorum composed by Giovanni Alcherio, an artistic advisor in Milan (Lombardy region, northern Italy) between 1382 and 1411 (Soldano Tosatti 1991). The Tabula survives in a copy made in 1431 by the Parisian notary Jean Lebègue (Paris, Bibliothéque Nationale, MS. lat. 6741), a learned royal chancellor, humanist and artistic advisor to Jean de Berry (Merryfield 1999; Soldano Tosatti 1983). The text provides 352 recipes for pigments (including those already given by Eraclius and Theophilus), which the author collected in the course of his life and working activity. As an advisor and agent for artists employed on the cathedral building site in Milan, Alcherio repeatedly visited Paris and many Italian cities such as Genoa (Liguria region, northern Italy), Bologna (Emilia region, central Italy) and Venice (Veneto region, northern Italy), surveying the most popular painting techniques and gathering direct information from renowned artists as Michelino da Besozzo, Jacques Coene and Giovanni da Modena. Alcherio was a sensitive observer of Gothic culture. His anthology is one of the earliest testimonies to the trend towards the use of increasingly transparent colours, mostly obtained from organic pigments, which contributed to the great development of the use of glazes in the late fifteenth century. Jean Lebègue, for his part, added some recipes in French to the original manuscript, enriching it further.

\section{Model books, iconographic guides, pattern repertoires}

Although model books do not provide technical instructions on how wall paintings were to be done and pigments manufactured, they nonetheless provide key references to formal and iconographical matters, and also, more generally, to how compositional ideas developed and particular motifs were disseminated in distant places, fostering cultural hybridisation within Europe and the Mediterranean. In other words, they form integral part of workshop practices, providing complementary information to those offered by technical treatises and recipe books.

Throughout the Middle Ages, the practice of copying existing works was central to artistic production, reflecting the value attributed to tradition within the technical and practical customs of artistic practice. The anonymous author of the Pictor in Carmine, a treatise dated from the twelfth century intended for painters, containing the largest known collection of types and antitypes from the Old and New Testaments (James 1951; Wirth 2006), is quite explicit in saying that he intends to provide an anthology of suitable subjects for the decoration of church interiors in order to guide painters and orientate their creativity. Several documentary pieces of evidence referred to the practice of copying existing works survive, including a letter from the second century which contains a request for a model for weaving (Horak 1992), and a document from the thirteenth century which testifies that a workshop had been established in St Albans (Hertfordshire, southern England) to provide a copy of King Henry III's altar (Lewis 1987).

Typically, the activity of copying was carried out by means of intermediary tools intended to facilitate the process, referred to in sources as models, 'exemplum', 'patron' or even 'imago' and 'similitudo'. Given that they were regarded as practical tools to be used by painters in their projects, they were generally discarded when the work was completed to be replaced with new ones, and hence only seldom do they survive (Scheller 1995; Kessler 1997; Jenni 2000). As far as it can be inferred from sources, the earliest models consisted of loose sheets made of papyrus or parchment; already in the Vita sancti Pancratii from the beginning of the eighth century, however, reference is made to two proper volumes containing models to be used in church decoration, and precisely Old and New Testament figures, which were indeed employed by missionaries in Sicily (southern Italy) to decorate the new churches they built there (Kitzinger 1960; Mango 1972).

The only remaining material evidence of models used for fresco paintings, comprising a coherent set of images, are two parchments. The first one is a thirteenth-century parchment scroll preserved in the Biblioteca Capitolare of Vercelli (Piedmont region, northern Italy), which contains eighteen episodes from the Acts of the Apostles in narrative sequences. These images had a practical function, as they were intended as references for painters involved in the restoration of the damaged frescoes in the parish church of $\mathrm{St}$ Eusebio in Vercelli (Scheller 1995). The second exemplar is a parchment sheet of considerable size $(39.5 \times 58.5 \mathrm{~cm})$ that dated from the thirteenth century, kept in the library of the Archabbay of St Peter in Salzburg, Austria. It contains over 30 scenes set within a geometric partition, illustrating the 
iconographic programme that was to be painted on the walls and dome of a chapel conceived in a similar way to those still existing in the cathedral of Gurk, a suffragan church of Salzburg (Geymonat 2013).

The two most renowned surviving model books, both dating from the mid-thirteenth century, contain a similar set of figures, which were apparently copied after extent works and served as visual and memorial aids (Geymonat 2018). The first one is the so-called Musterbuch, which forms part of an anthology comprised in a manuscript preserved in Wolfenbüttel, Germany (Herzog August Bibliothek, MS. Guelf. 61.2 Aug. 8). Twelve pages present drawings made by an artist ca. 1240 during his travelling in the Balcans and Venice. About 30 figures are copied after wall paintings, mosaics, manuscripts and sculptures that the artist saw during the trip (Geymonat 2012, 2016). Equally well known is the coeval Livre de Portraiture, a sketchbook from around 1235 by the French sculptor and architect Villard de Honnecourt (Paris, Bibliothèque Nationale, MS. fr. 19,093). The drawings seem to have originated as occasional sketches that the artist made in various locations between the 1220s and the 1230s. The collection is not conceived as a coherent set, but rather as a compilation of figures derived from disparate objects, artworks, buildings that attracted the artist's attention. Only later were the drawings organised in consistent groups, that were bound together, presumably because the author felt that they could be used as visual aids (Barnes 2009; Bork 2011; Geymonat 2015; Wirth 2015). Indeed, the notebook was kept as a sort of construction manual and was later amended between 1250 and 1260 and again at the end of the century.

Later model books manifest a shift in the nature of drawings, which were no longer conceived as mere copies after existing artworks, but rather free interpretations created by artists, training devices for memory and imagination, in which new adventurous solutions were explored and tested (Scheller 1995). This change went hand in hand with an evolution in the status of the artist. As we have seen, in the late fourteenth century Cennino encouraged artists to exercise their creativity by means of investigating nature, conceiving new compositions in a way similar to poets. In fact, numerous late medieval model books contain studies of nature, as well as depictions of antiquities and inventive figures, marking a new stylistic and formal experimentalism, free from the need to perpetuate previous traditions. Mention should therefore be made of the book of drawings by Giovannino de' Grassi preserved in Bergamo, Italy (1389-1398, Biblioteca Civica 'A. Mai', MS. Cassaf. 1.21), with a copious collection of drawings of animals, human figures, motifs for embroidery and a figured alphabet (Recanati 2005; Aldrovandi 2006). Many of these compositions appear in later works of art, such as the Offiziolo Landau-Finaly (Florence, Biblioteca Nazionale, MS. Landau Finaly 22) and the Très Riches Heures by Jean de Berry (1413-1416, Chantilly, France, Museé Condé, MS. 1284), showing that Giovannino's book was indeed used as a source of patterns and figures. Equally innovative in their approach to drawing are the Libretto degli Anacoreti, produced in the workshop of Michelino da Besozzo with a copious repertoire of images of hermitic subjects, as well as naturalistic and courtly themes (Delle Foglie 2006). In addition, the Libro di Giusto, by a master active in Rome around 1450, which passes on the manuscript and illustrative tradition of the Canzone delle Virtù e delle Scienze by Bartolomeo de' Bartoli, testifying to the humanistic culture of the lost cycle of frescoes painted by Masolino da Panicale in the Palazzo Orsini di Montegiordano in Rome (Delle Foglia 2019) .

Some important European model and drawing books are also worth mentioning, including the Vademecum of Wien, Austria, produced in Bohemia ca. 1400-1410 (Kunstistorisches Museum Sammlung für Plastik und Kunstgewerbe, MS. 5003-5004; Scheller 1995); also, two collections of models connected to Jacquemart de Hesdin and Jaques Daliwes respectively (New York, The Pierpont Morgan Library, MS. 346, late quarter of the fourteenth century; Berlin, Staatsbibliothek-Preussischer Kulturbesitz, Liber Picturatus, MS. A 74, ca. 1400-1429), both from the Franco-Flemish region (Scheller 1995). Finally, a collection produced in England in the last quarter of the fourteenth century, with drawings from different periods showing domestic animals and beasts of pray, together with standing and seated human figures in different poses and gestures (Cambridge, Magdalene College, Pepysian Library, MS. 1916; Scheller 1995); and the so-called Icelandic notebook, with drawings from the second half of the fourteenth and the late fifteenth centuries (Reykjavik, Iceland, Stofnung Arna Magnussonar, MS. AM. 673a, III, 4; Scheller 1995).

\section{Wall painting techniques}

\section{A fresco, A secco and Mezzo fresco painting techniques}

It is important to clarify, first of all, that there exist different wall painting techniques, which differ according to the state of the plaster at the time of painting, i.e. wet or dry, its preparation, the pigments and the binders used (Conti 1988; Rinaldi 1998; Hoeniger 2003; Ling 2003). In addition to being employed individually, these techniques were often used together-in fact, most medieval wall paintings consist of a combination of a fresco, a secco and mezzo fresco.

A fresco is a wall painting technique in which pigments are dissolved in water only (Figs. 1, 2a). Pigments are applied to fresh, wet lime plaster (the intonaco), laid over the underlying layer of plaster called arriccio. Inorganic pigments 
Fig. 1 The anatomy of a fresco, showing the superimposed layers of materials (Graphic (C) Paolo Vedovetto)
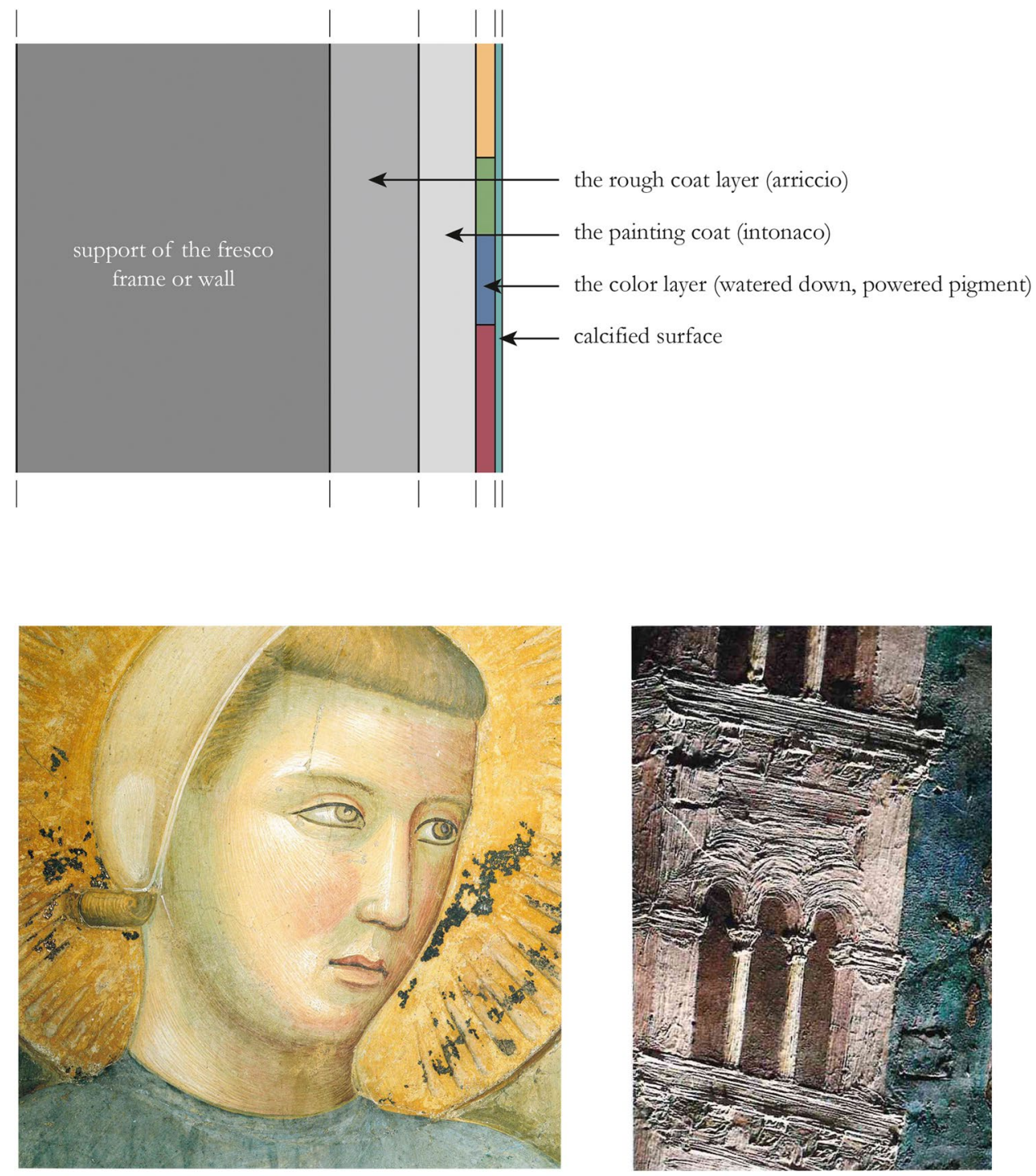

b
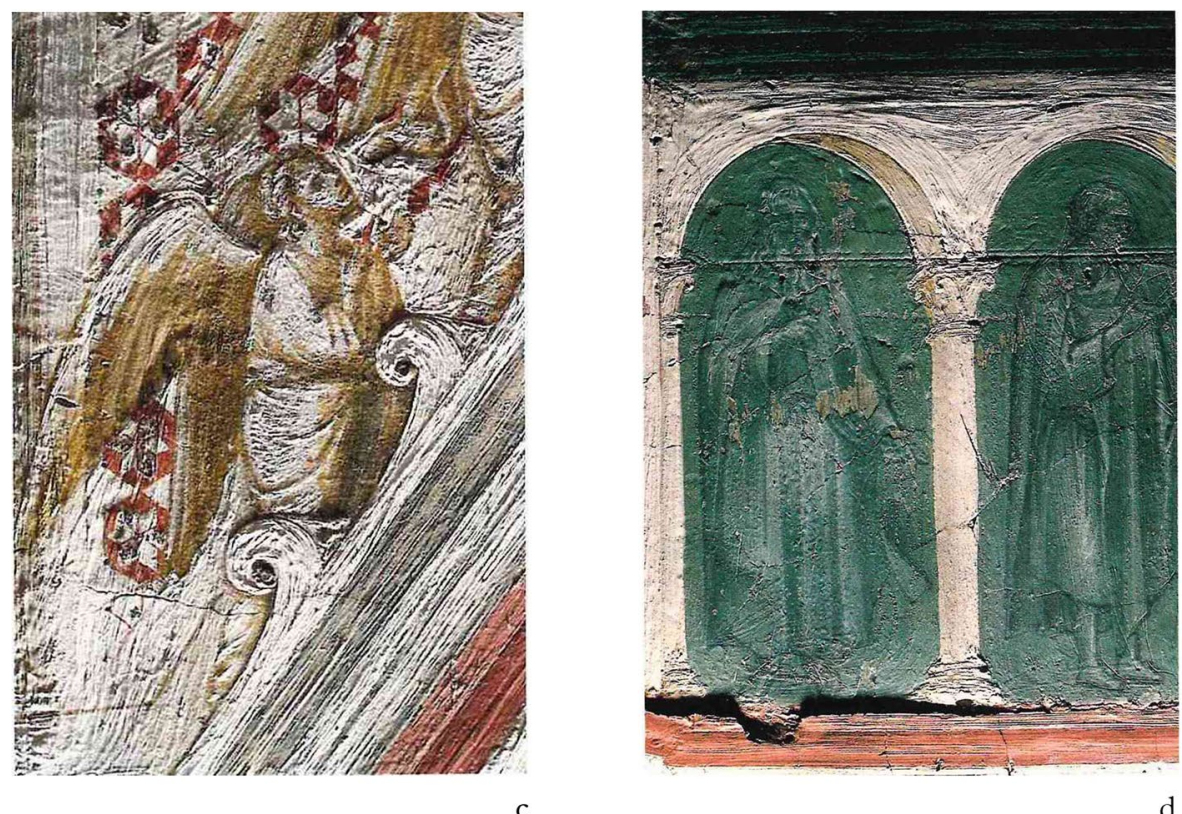
are the most suitable to be used in fresco (although organic ones such as indigo and lacquers were sometimes used); in fact, all the others would react with water resulting in hue variations or would not adhere sufficiently to the wet plaster. According to the formula $\mathrm{Ca}(\mathrm{OH})_{2}+\mathrm{CO}_{2} \rightarrow \mathrm{CaCO}_{3}+\mathrm{H}_{2} \mathrm{O}$, as the wall dries the calcium hydroxide contained in the plaster combines with carbon dioxide found in the atmosphere and forms calcium carbonate (Procacci and Guarnieri 1975; Mayer 1987; Cordaro 1991; Colalucci 2003a). During this process, the organic pigments dissolved in water are embedded to the wall by the carbonation of the calcium hydroxide from the wet plaster and form an additional fine layer on the wall surface. The drying of the fresco needs to be gradual and homogeneous. A fresco painting is technically demanding. In the Middle Ages, it was usually carried out on a large scale, so painters had to be accurate in drawing up the composition. As we have seen, models and iconographic guides could be used to setting up the final layout and, as we shall see in the following sections of this paper, artists employed a variety of tools and techniques to transfer the composition on the wall. The procedures of fresco painting are known not only from the numerous investigations carried out during conservation and restoration works on many surviving paintings, but also from the meticulous descriptions and instructions contained in various medieval treatises, above all Cennino's Libro dell'arte, which describes the practices and techniques used in fourteenth-century workshops of Giottesque tradition (Cennini, 2012, 2015) .

A secco is carried out on dry plaster, employing a combination of pigments, media and binders used to secure the pigments to the dry rendering (Mora et al. 1999, 2001; Colalucci 2003c; Fernetti 2005). The binders used include casein, egg, glues obtained from animal skins, such as rabbit skin glue (to which milk could be added) and oils. For a secco painting, Cennino recommends bounding pigments in whole egg mixed with fig-tree latex. He warned not to use too much medium, as that would cause the colour to break up and disjoin from the wall. According to Cennino, the surface to which the paint was to be applied had to be carefully smoothed and prepared with a layer of dilute glue before egg tempera with fig-tree latex was applied (Cennini 2012, 2015). A secco paintings are generally less durable than a fresco ones, since pigments are not trapped to the wall and in addition organic binders are vulnerable to biological attack by microorganism and are subject to other alteration phenomena. For this reason, although a secco is generally easier to execute than a fresco, it was not highly regarded by painters nor patrons. Still, a secco technique was often employed to add finishing touches to an a fresco paint, or to paint the most demanding details, or again to retouch small portions of the composition.

Mezzo fresco is a sort of an intermediate technique (Fig. 2b, c, d). It is basically an a fresco technique in which pigments are applied to wet lime plaster. Yet, rather than being ground in water, they are dissolved in lime water, or milk of line, which increase their opacity and also made them thicker (Mora et al. 1999, 2001; Colalucci 2003b; Piovesan et al. 2012).

As have been said already, a number of techniques were often used together in different layers of the same painting. This was quite demanding, as pigments reacted in different ways and resulted in diverse hues and thickness. Cennino praised the ability of Giotto in painting frescoes and mastering a combination of techniques to obtain a variety of final effects and colour results, as we shall see in greater details (Cennini 2012, 2015).

\section{Preparation of the wall}

The wall can be made either of stone or brick, while it would be advisable to avoid mixed material, as such a variety would cause differences in the painting. Ideally, it should be moisture-free and have a rough surface to allow the application of mortar and plaster. According to Cennino, before applying the mortar, the wall should be dusted to remove residues that would compromise adhesion. Then, the surface should be wetted, to avoid that the watery solution contained in the mortar penetrates into the wall, impoverishing the plaster of its binder (Urbani 1978). Finally, two or three layers of mortar should be applied to flatten any unevenness of the surface. After smoothing out the irregularities of the wall, the layers of plaster, arriccio and intonachino, are laid down and painted over (Cennini 2012, 2015).

\section{Arriccio and Intonachino}

The first layer of plaster, known as arriccio, had to be left with a rough finish to facilitate the adhesion of the superimposed layers of plaster. According to a document dated 26 October 1410, the execution of the arriccio was generally carried out by qualified craftsmen (Piattoli 1930; Zanardi 1996). A suitable formula for obtaining a good arriccio is to use one part of slaked lime (calcium hydroxide) and two/ three parts of river silica sand (sea sand is obviously not to be used since it contains salts that would cause deterioration to the painting). The mixture should be free of clay, which would create cracks. The thickness of arriccio is ca. $1 \mathrm{~cm}$.

The plaster intended to receive the colour, also called intonachino, is composed of fine sand, marble powder and lime in almost equal parts. It is applied onto the arriccio which has been previously wetted. In a fresco painting, it must remain wet for the entire duration of the work. All ancient sources, from Vitruvius to Cennino, emphasise the need to work with slaked lime, as otherwise lumps would remain, which would make the surface fragile and uneven. Painters were advised to prepare a quantity of material 
sufficient for 15 or 20 working days, a practice that would limit any possible risks of variation in colour, grain size or technical behaviour.

The thickness and composition of the arriccio and intonachino varied greatly over time, and sometimes even within the same building site. The overall thickness of the preparatory layers in the Arena Chapel in Padua, for instance, painted by Giotto and his workshop in 1303-1305, reaches a maximum of $2-2.5 \mathrm{~cm}$, distributed as 0.5 for the arriccio and 0.5 for the intonachino. This thickness, however, is not uniform and varies considerably for the preparatory layers to the point of becoming only a few millimetres thick in correspondence with the stone elements that make up the structure of the chapel openings (doors and windows) (Capanna and Guglielmi 2005). The surface of the intonachino is refined differently according to the type of painting it was intended for. In correspondence to the architectural partition elements, the starry sky of the vault and the background of the narrative stories, the intonachino is far less smooth than the one used for human figures (Capanna and Guglielmi 2005).

\section{Pontate and Giornate}

A distinction should be drawn between two different ways of applying the layer of plaster. In the first system, called pontate, which literally means 'scaffolding', the plaster is applied in broad horizontal sections that roughly correspond to successively lower stages of the scaffolding (Fig. 3a). This method was common until the end of the thirteenth century and was used even later when large areas were to be executed in a secco painting or could be completed quickly in a fresco painting, such as backgrounds of blue sky. Instead, for a proper a fresco painting, the plaster was applied in smaller patches of different sizes, corresponding to the area that the artist would paint in one working day ('giornata') while the plaster was wet (Fig. 3b, c). This method is known as giornate and while it was commonly used in the Roman time, in the Middle Ages it started to gain ground at the end of the thirteenth century, initially in the Upper Church of St Francis in Assisi and then in other artistic projects as well, when a new approach to painting, with a keen interest for reality, gestures, facial expressions, naturalistic elements, resulted in the execution of smaller, yet much more refined and detailed, areas of painting per day (Fig. 3d) (Cordaro 1991; Zanardi 1996, 2002; Maltese 2019).

The joinings of each giornata are usually discernible upon a close examination of the painted surface, and they disclose the order in which the patches were painted, since each successive patch slightly overlaps the preceding one. In addition, they make it possible to estimate the number of working days needed to complete a project. For instance, it has been calculated that the frescoes in the Arena Chapel in
Padua were painted in 852 days, some of them, naturally, the simultaneous work of several painters and assistants. More specifically, it is estimated the entrance wall of the chapel was painted in 193 days, the vault in 88 days, the long south and north walls in 245 and 250 days respectively, and finally the choir arch in 76 days (Gilbert, 2003) .

\section{Laying out and transferring of the composition}

Wall painting techniques required a well organised and efficient system for laying out the composition and transferring it to the wall (Nimmo and Olivetti 1985-1986). These techniques met several needs: firstly, they allowed for the work to be completed in a relatively short time, before the plaster dries; secondly, they secure stylistic homogeneity in the different parts of the composition, i.e. both those painted by the master and those completed by the assistants; finally, they guarantee that the proportions of the figures, landscapes and buildings are always the same in all the different parts of the composition.

\section{Cord snapping}

First of all, the vertical, horizontal and diagonal lines of the composition were laid out on the arriccio by imprinting a snapping cord, either a plumb line or cords held in tension between two nails (Zanardi 1996, 2002). This preparatory procedure, essential for establishing a first general partition of the areas of space, is described in detail by Cennini (2012, 2015). The cord, soaked in colour thinned in water, was pulled tight and then pressed against the wet arriccio, leaving mark of the colour and the imprint as well (Mora et al. 1984, 1999, 2001). Signs of cords are often visible on wall paintings, providing crucial insight on workshop procedures and techniques, which can vary from artist to artist, and sometimes from project to project of the same painter. When the shape to be delineated was circular, a compass was used to trace its outline.

\section{Sinopia}

Once the overall composition was laid out, figures could be drawn on the arriccio (Fig. 4). Usually, they were initially sketched with charcoal, and then traced over with red ochre (sinopia) mixed with water (Procacci 1961). It basically formed the first indication of the result to be obtained; its degree of accuracy or roughness varied according to the artists, workshop praxis and the division of tasks within the workshop. It is not uncommon for the outline identified with the sinopia to be modified during the final execution. The term sinopia, first introduced by Cennino in his treatise $(2012,2015)$, came into use in Italy after the Second World War, mainly as a result of major 
Fig. 3 Pontate and Giornate methods of wall paintings. Acquanegre sul Chiese (Mantova, Lombardy, Italy), Church of S. Tommaso, Graphic survey of the pontate (a); Assisi, Church of St Francis, Giotto's the Homage of a Simple Man, showing the actual fresco (b) and the graphic survey of the giornate (c); Assisi, Church of St Francis, detail of Francis's hand from the Sermon to the Birds, showing the patch of a giornata (d) (Graphic (C) Tosatti 2015; Graphic and Photos (C) Zanardi 1996)
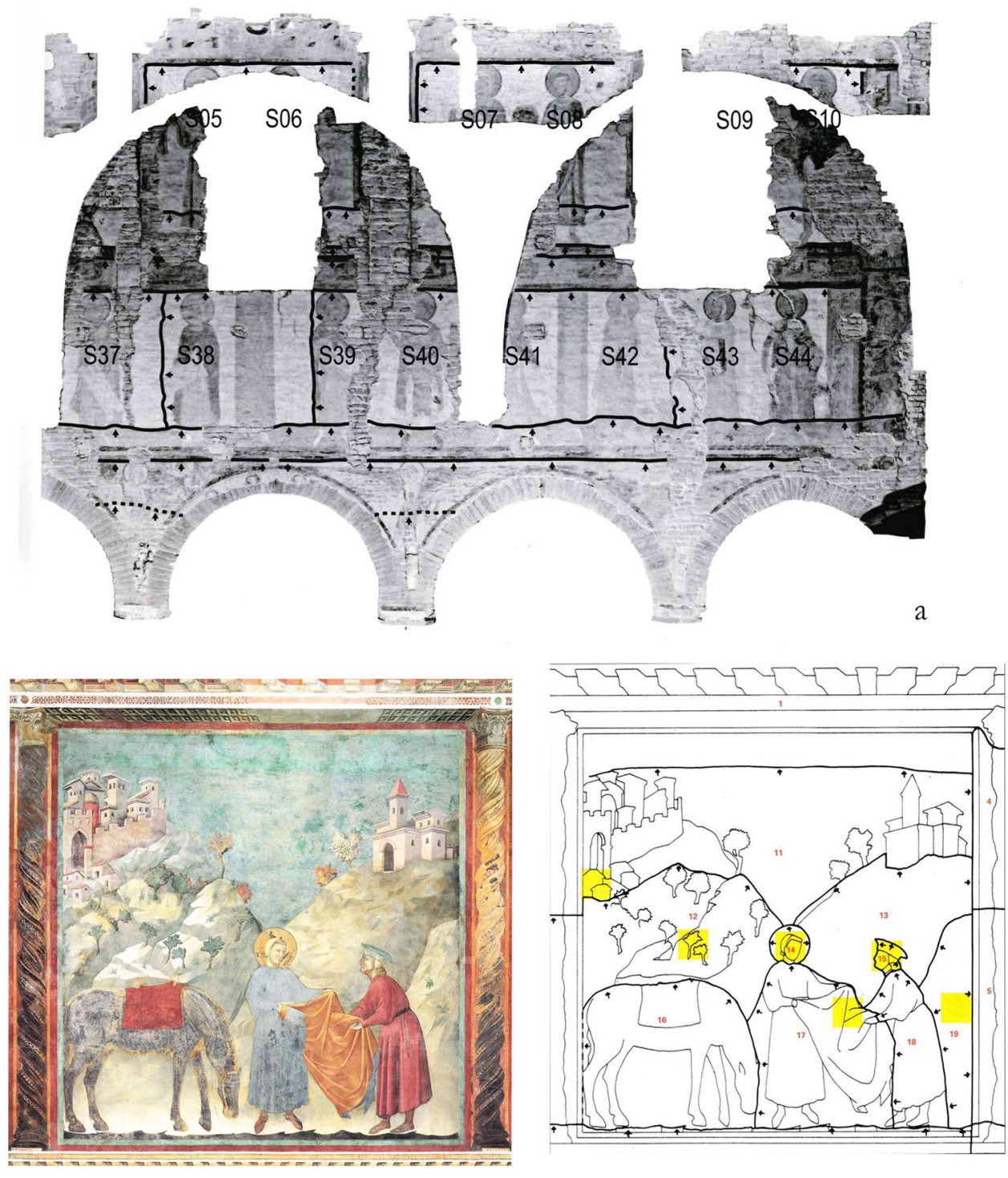

$\mathrm{b}$

C

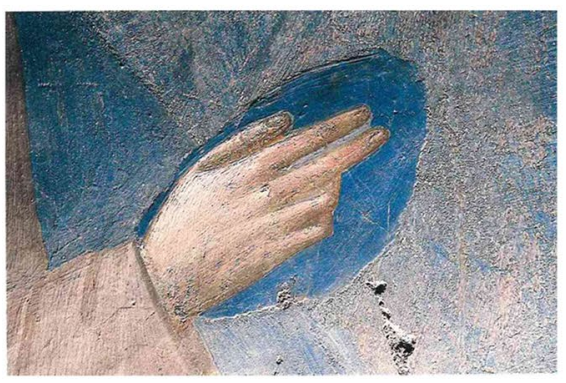

d

restoration campaigns, with the detachment of thirteenth to fifteenth centuries frescoes that revealed the existence of an incredible number of sinopia underdrawings. The largest group of sinopie discovered on such occasion is on display at the Museo delle Sinopie in Pisa, Tuscany (Dodge 1978; Caleca 1979; Ferretti 1980).

\section{Preparatory drawing}

Once the sinopia was traced on the arriccio, the second layer of plaster, or intonachino, was applied starting from the top and continuing downwards. The amount of plaster was determined according to the painting technique used; 


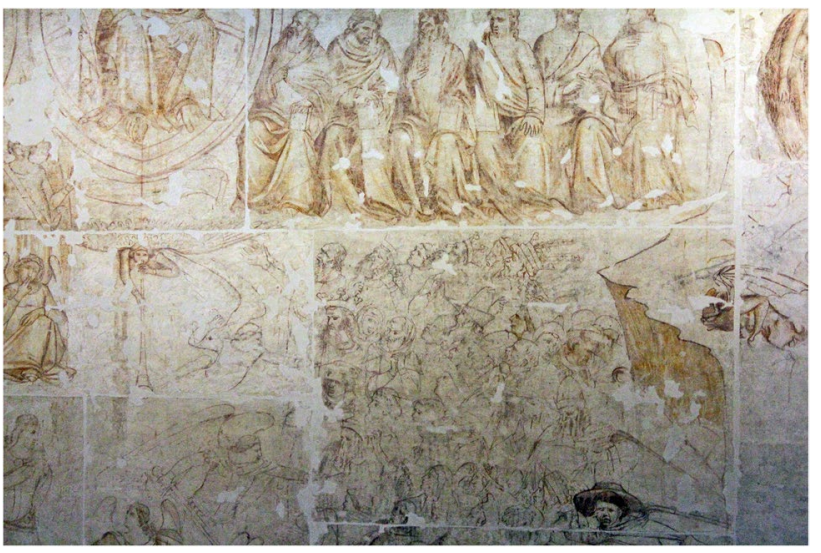

Fig. 4 Sinopia. Pisa, Museo delle Sinopie (Photo (c) Creative Commons)

for a fresco paintings, to be painted on wet plaster, it needed to be limited, while it could be larger for a secco painting. After having carefully smoothed the surface, the operation of snapping the cords was repeated (Fig. 5a, b) and a second preparatory drawing was sketched with a brush soaked in yellow ochre. Compasses were used to trace the curved lines (Fig. 5c), such as those in correspondence with the haloes, or with ornamental motifs as the cosmatesques, and the straight contours of the architecture were also delineated (Zanardi 1996, 2002; Maltese 2019). The plaster was then pressed down with the tip of the trowel to make it smooth and compact, but also to bring the calcium hydroxide of the fresh mortar to the surface, allowing for better carbonation of the colour (Maltese 2019).

Different pigments could be used to sketch the preparatory drawings, according to the final effects a painter wished to achieve in terms of colour palette. In fact, it is known that a fresco painting allows a certain transparency to be maintained; hence, the preparatory drawings may be visible underneath the painted layer. Scientific examinations have revealed that in the paintings in Arena Chapel in Padua by Giotto and his workshop the preparatory drawing is executed with a brush, using different pigments from area to area. In areas that were to be painted blue, for instance, preparatory drawings are traced either in red earth and yellow ochre with black shading (Fig. 6), or in grey (Capanna and Guglielmi 2005). In the church of St Francis in Assisi at least two different colours for the preparatory drawing were used by Giotto and his workshop; it is interesting to notice that yellow ochre was generally employed for the incarnation, in order to
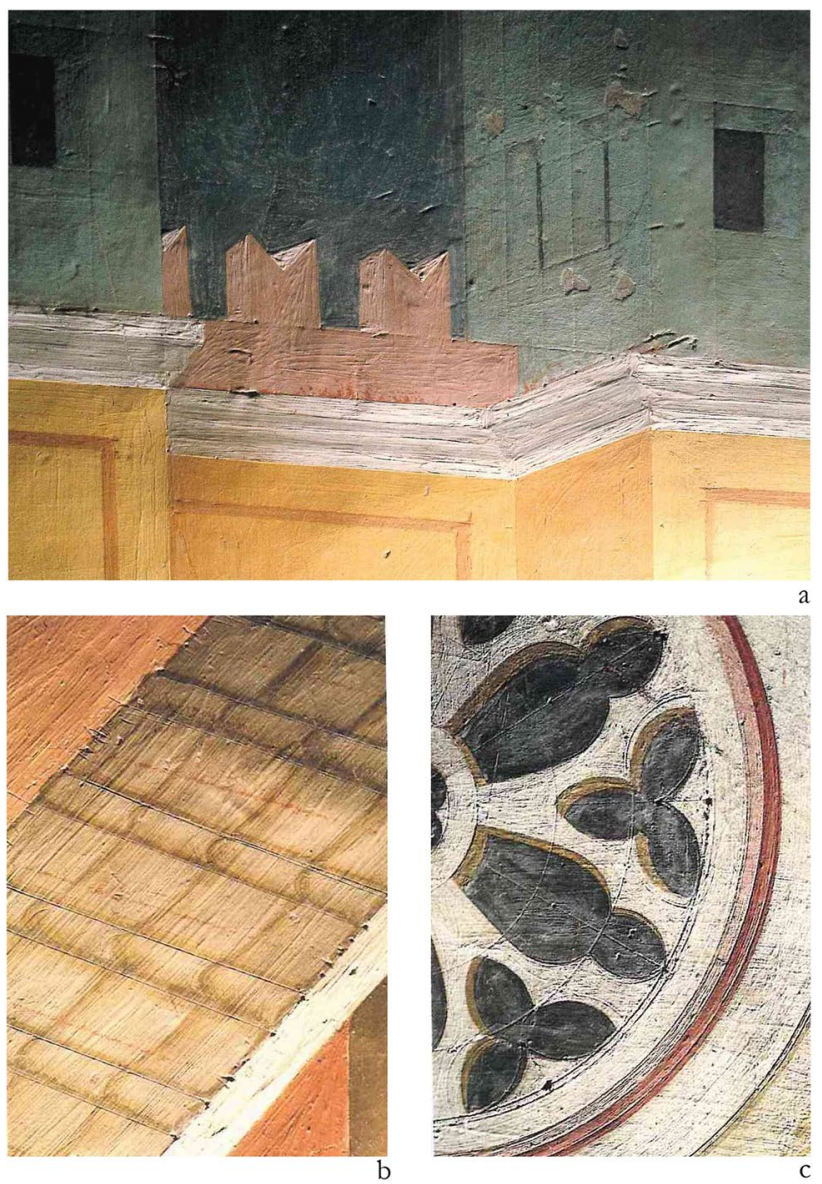

Fig. 5 Traces of incisions on the intonachino, obtained with cords and compasses. Assisi, Church of St Francis, details from Giotto's The Ecstasy of St Francis (a); the Renunciation of Worldly Goods (b); the Confession of a Woman raised from the Dead (c) (Photos (C) Zanardi 1996)

obtain a drawing whose chromatic value would not affect the superimposed layers of light colours (Zanardi 1996).

\section{Models, patroni and cartoons}

The preparatory drawing provided the general outline of the composition, which had already been tested with the sinopia, and yet needed to be further refined in order to reach a suitable final result. One of the most popular methods implied the use of waxed paper (therefore transparent) templates known as patroni; the procedure to produce this type of transparent paper was described by Cennino in chapter XXIII of his treatise (Cennini 2012, 2015), but also in the Illuminierbuch of Valentin Boltz (Boltz 1549), which devoted an entire chapter to Patronepapyr, manufactured by impregnating a sheet of paper with hot linseed oil added to Armenian bolus and asafoetida, i.e. the dried latex exuded from the rhizome of several species of the 


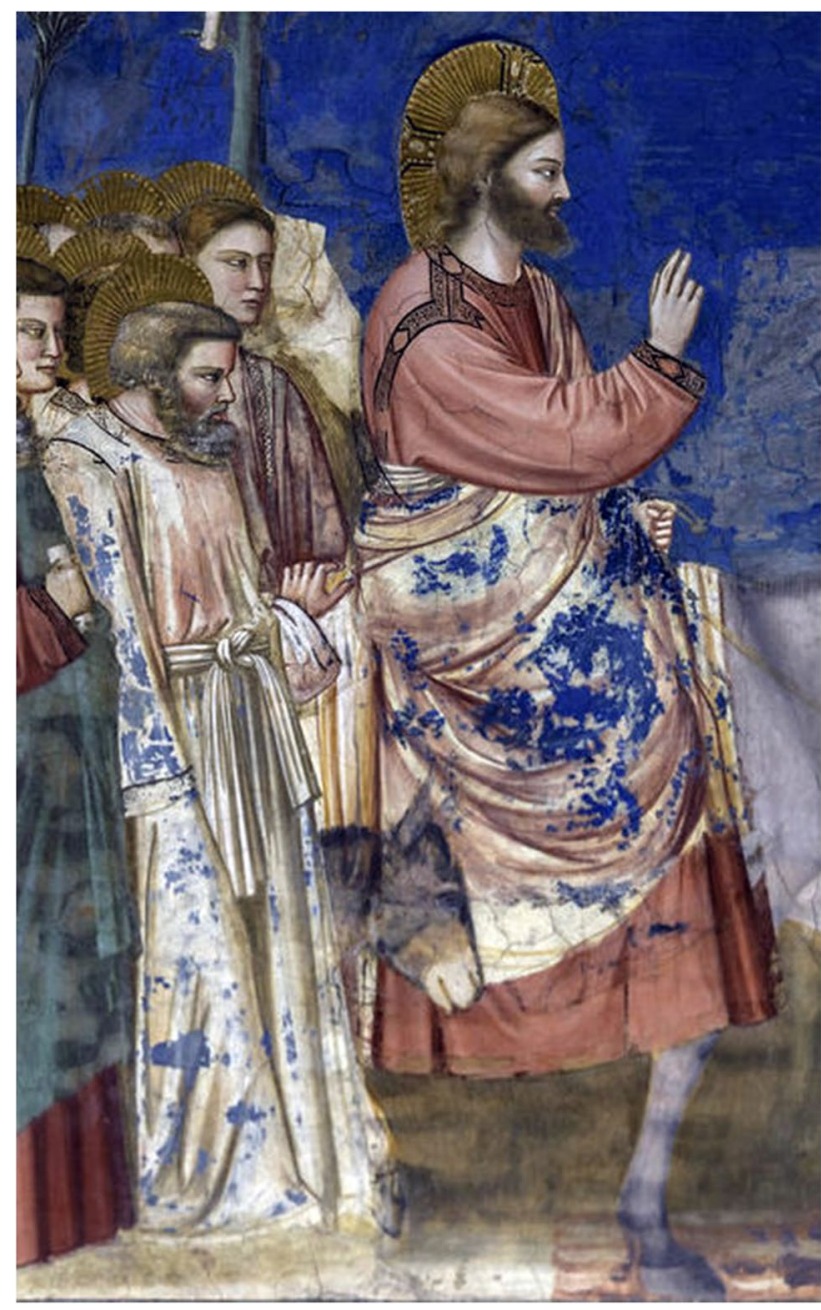

Fig. 6 Underdrawings visible in correspondence with the mantle of Christ and the dress worn by St Peter, where the a secco layer of azurite got lost. Padua, Arena Chapel, detail from Giotto's The Entrance into Jerusalem (Photo (C) Creative Commons)

perennial herb Ferula. There is also a recipe for making paper 'as transparent as glass' in the text known as Manoscritto di Padova, which prescribes similar ingredients to those mentioned by Boltz: hot walnut oil, Greek pitch and powdered white litharge, a natural mineral form of lead oxide (Merryfield 1999).

The nature of patroni as working tools, as well as the moistening of the support with wax and oil, which makes them rigid and fragile, has led to their almost complete loss. Some examples were accidentally found inside putlog holes during the restoration works carried out by the Istituto Centrale del Restauro between 1959 and 1964 in the chapel of San Nicola di Tolentino (Macerata, in the Marche region, Italy), frescoed around 1325 by Pietro da Rimini (Del Serra 1986; Zanardi 2002). The silhouette of a hand in oiled paper was also found during the restorations carried out in the 1950s on the Giottesque frescoes in the Abbey of Pomposa, near Ferrara, Emilia region, Italy (Zanardi 2002).

The first document mentioning patroni dates from 1307: in the records related to the decoration of the chapel of St. Stephen's in Westminster, London, 'skrowys' (parchments) used to make 'pronnos' (patroni) are noted (Eastlake 1960). Another evidence is provided by the Vatican Palace accounts, which list payments made on the $4^{\text {th }}$ and $30^{\text {th }}$ August 1369 respectively: the first one was intended to buy paper to produce patroni, the second one to purchase materials to wax the paper (Müntz 1890; Zanardi 2002). We can thus assume that it was common practice to wax the papers used for patroni, hence increasing their material consistency, and in addition making them transparent. Finally, the wax made the paper water-repellent, preserving it from damages that could result from contact with humidity and the basic nature of wet plaster, as well as from the water in which the pigments were mixed.

At least three documents indicate that patroni were considered as proper working tools, which were highly prized by painters. The first, dated 1361 , is a testamentary bequest by a painter from Lyon, Jean Chatard, to another painter of 'all his painted parchments, called patroni, to be used as models for painting' (Scheller 1995). The second, from 1398, concerns Jacquemart de Hasdin, one of Jean de Berry's masters, who was accused by John of Holland of having forced the lock of one of his trunks kept at the Duke's palace in Poitiers, France, in order to steal his pigments and patroni (Romano 1963; Scheller 1963; Meiss 1967). The third document concerns Bernardino Simondi, a painter from Saluzzo (Cuneo, Piedmont region), who in 1497 bequeathed all his patroni to the painters Claudio Ruffi, Antonio Regis and Honorato Labe (Zanardi 1996). Finally, a document pertaining to the Cathedral of Dijon, France, attests that in 1398-1399 the painter Jean Malouel was given some large 'papier de Lombardie' to make drawings which were to be used to derive patroni from them, to be employed as working implements (Meiss 1967; Zanardi 1996).

To mention just one example which has been scrutinised in depth, it is worth recalling that examinations undertaken during recent restoration campaigns have revealed that four diverse patroni were used in the church of St Francis in Assisi, three of which were replicated many times with slight variations (Fig. 7a, b, c) (Zanardi 1996, 2002). It appears that patroni were mainly used as models for faces and hands, while other kinds of devices seem to have been used for other parts of the composition, including cartoons, mainly employed for the repetition of decorative motifs and ornamental patterns (Zanardi 1996, 2002). Cartoons were used by artists from the early medieval period (Millidge 2003). Cennino gave detailed instructions for the execution of ornamental patterns using 
Fig. 7 The layout of a Patrono replicated three times with minor variations $(\mathbf{a}, \mathbf{b}, \mathbf{c})$. Assisi, Church of St Francis, various episodes (Drawings (C) Zanardi 1996)

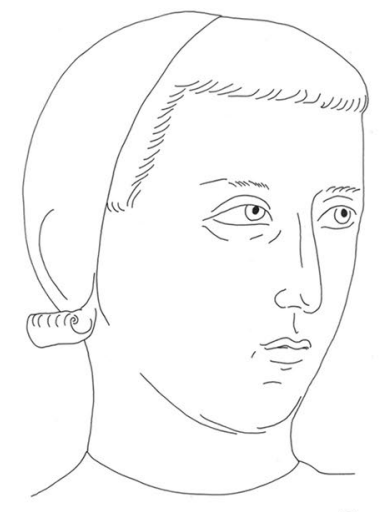

a
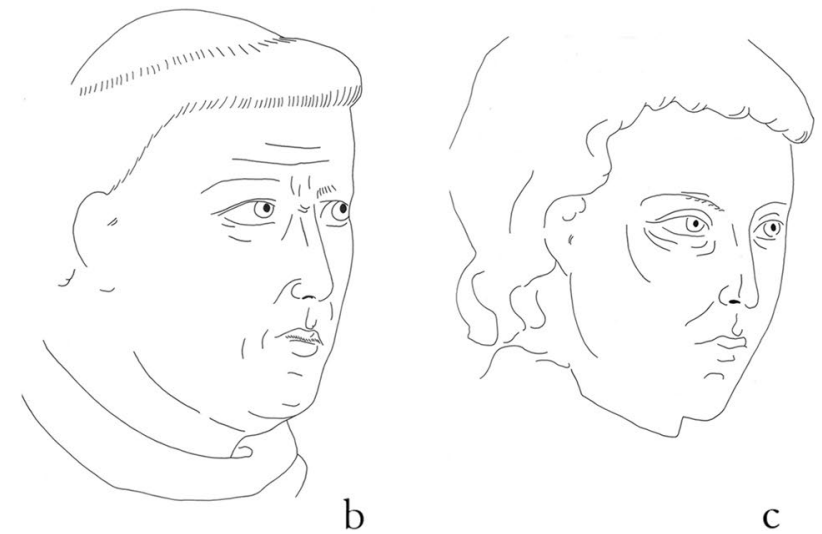

b a parchment cartoon, a procedure that has been verified scientifically in panel paintings produced in Tuscany during that period (Cennini 2012, 2015).

\section{Pouncing and tracing}

Both patroni and cartoons were generally produced on the same scale as the final work and were usually fairly detailed. Two methods are known to have been used to transfer the design to the wall: pouncing and tracing (Procacci and Guarnieri 1975). In the first method, the outlines of the drawing were perforated with a needle or stylus. The sheet of paper was attached to the support. A bag containing powdered charcoal was then tapped onto the sheet: passing through the holes, the powder left coloured dots on the surface. At this point, the series of dots only needed to be joined up to replicate the drawing. In the second method, i.e. tracing, the back of the patrono or cartoon was rubbed over with chalk. The paper was then laid flat against the support, and the main lines of the drawing were drawn over with a stylus. The chalk from the back of the cartoon was transferred to the wall, which also retained the incisions (Zanardi 1996, 2002; Mora et al. 1999, 2001; Maltese 2019).

A combination of the two methods was also possible, according to the final result to be achieved-but also to the type of element to be outlined. In the Arena Chapel in Padua, for instance, a variety of tracings has been observed during examinations undertaken in the course of restoration campaigns, showing that different methods could also be used at different stages of the work: within the narrative scenes, buildings and architectural elements seem to have been outlined with tracing on the wet intonachino; additional tracings on the wet plaster were used to limit the areas that were to be decorated with metal foils. Finally, pouncing and tracing on the dry plaster were employed to mark the areas were the most demanding details had to be completed in $a$ secco technique (Capanna and Guglielmi 2005).

\section{Paint application}

Once the guidelines of the final composition had been traced, work could start on the painting. The process could continue for many hours, depending on the season and climate, until the plaster began to dry, forming its coating of calcium carbonate. In general, the best possible conditions for begin painting and work were 2 or 3 hours after the laying down of the intonaco. Cennino and other writers advised painters to prepare in advance all the needed materials, including pigments, brushes, and other tools (Bensi 1978-1979; Baroni 1998; Cennini 2012, 2015). Also, it was advisable to prepare colours in enough quantity to complete the composition, in order to avoid nuances variations. Ideally, colours should not be mixed on the palette since they would alter in tone and intensity in drying. Instead, the whole range of hues in their various tonal gradations would need to be prepared in advance and used individually. The colours were kept in jars of water called mestiche (Zanardi 1996, 2002; Mora et al. 1999, 2001; Maltese 2019).

The painters needed to be aware, and to measure the materials out accordingly, that pigments reacted differently in a fresco and a secco painting: in fact, when mixed in water and used in a fresco, they were considerably liquid and retained transparencies, while in a secco paint they tend to appear more full-bodied and opaquer. This had to be taken into close consideration in order to calibrate the final effects, especially in the frequent case of combined technique paintings.

Methods of paint application varied considerably and were substantially more complicated than contemporary treatises would suggest. Generally, single laying-in colours were applied over the preparatory drawings. Another very popular painting method was the so-called two-stage coloration, through which a relief effect was obtained by adding darker shading hues to the laying-in colour (Zanardi 1996, 2002; Maltese 2019). In the Mappae Clavicula and in the 
De coloribus et mixtionibus, this procedure was referred to as incidere, which literally means to incise. In fact, the final result resembles an incision on a metalwork, full as it is of dark lines that trace the composition and emphasise the relief. Finally, a third method existed, called three-stage coloration. In this case, highlights composed of the laying-in tone mixed with white were added to the laying-in and shading colours (Zanardi 1996, 2002; Maltese 2019). In the De coloribus, this procedure is called matizare. The final result generally looks more polished than in single- and two-stage coloration, with highlights giving a surface sheen and relief achieved by working up and down from the laying-in colour.

Fig. 8 Graphic reconstruction of paint application in sequence and superimposed layers to obtain skin tones. Acquanegre sul Chiese, Church of S. Tommaso (Graphic (c) Tosatti 2015)
All these methods required ingenuity and skillful ability, since colours that contain iron oxides tend to become darker as they dried, while those with a dark base usually become lighter. The application of highlights, then, but also the addition of darker hues, had to be carefully conducted.

Particular attention was paid to execution of skin tones (Fig. 8), for which three main methods existed (Fig. 9a, b, c). They are mentioned in contemporary manuals, especially in Cennino's Libro dell'Arte, where the procedures are described in detail (Cennini 2012, 2015), and have been verified on several wall paintings (Zanardi 1996, 2002; Pesenti 1997; Maltese 2019). Three layers of green hues
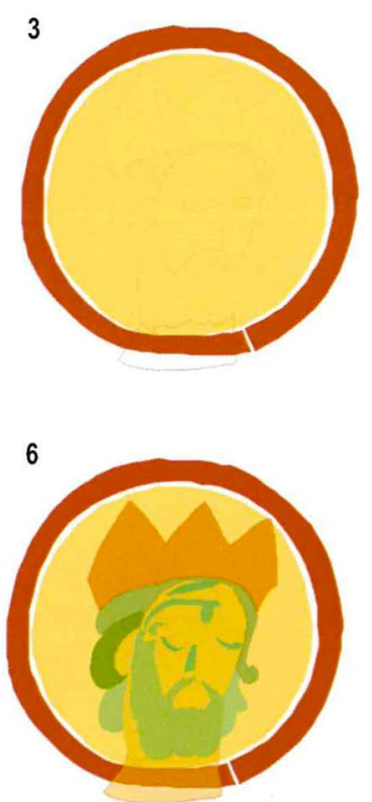

1
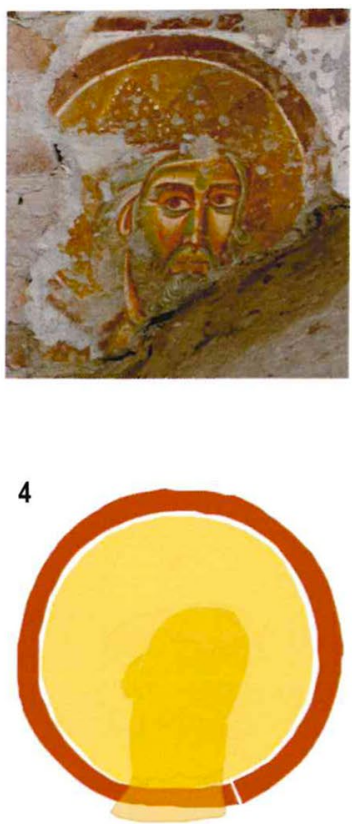

7
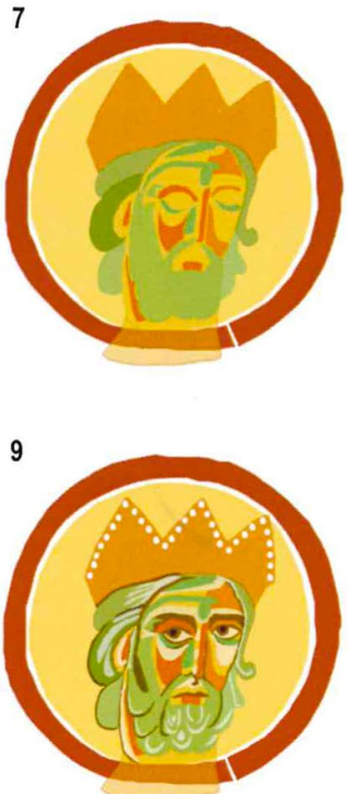

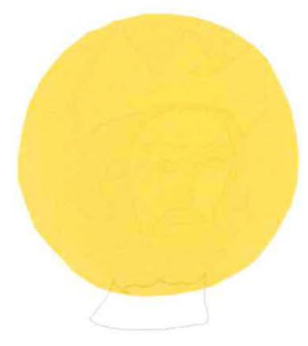

5

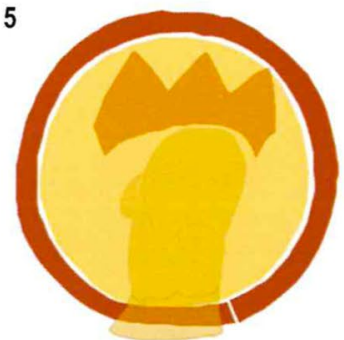

8

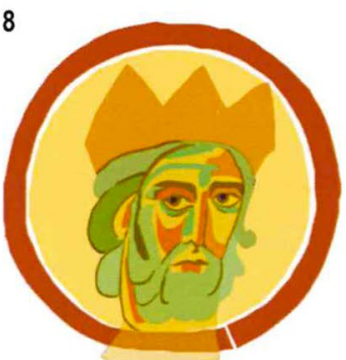


Fig. 9 Examples of the first, second and third method to apply skin tones. Assisi, Church of St Francis, details from Giotto's The Renunciation of Worldly Goods (a); the Confirmation of the Rule (b); the Homage of a Simple Man (c) (Photos (C) Zanardi 1996)
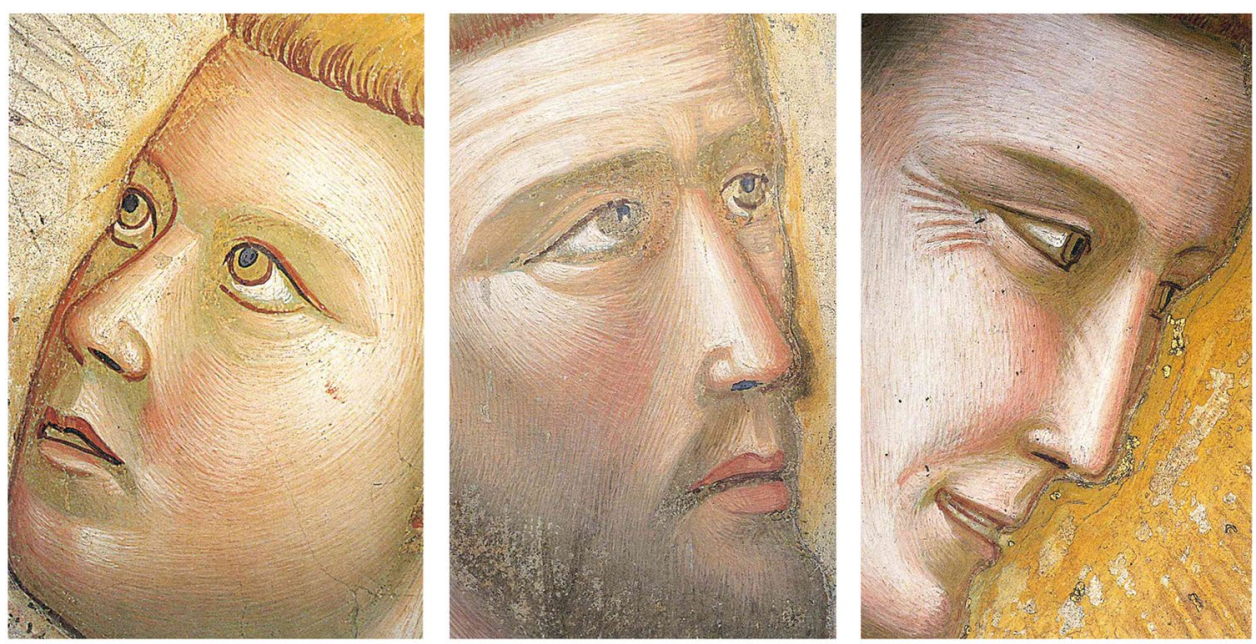

$\mathrm{b}$ were applied over the preparatory drawing, which, according to prescriptions, had to be done in yellow ochre in order not to interfere with the final hue. First of all, three different nuances of green colour were applied: a cooler one on the whole surface; a second, warmer one, to create the shades; and finally, a greenish-brown one to draw the facial features, nose, eyes and eyebrows. In the middle of the cheek, a bright pinkish meluzza had to be drawn, to emphasise the cheeckbone. Then, three layers of pinkish colour, from darker to lighter hues, were added. After that, white was applied to the reliefs, such as the tip of the nose, and on the eyes, while black was used to delineate the eyebrows, pupils and nostrils. According to Cennino (2012, 2015), while the sequence to paint skin tones with three different layers of hues was common, there existed three different methods to apply the painting, according to the final result that a painter wished to achieve; this technique has been verified during examinations undertaken in restoration campaigns especially on works executed by Giotto and his workshop, whose tradition Cennino adopted and handed down (Zanardi 1996, 2002).

Any areas that could not be painted in fresco were executed when the composition was finished, and the plaster had dried. These included finishing touches in a secco paint and egg tempera, mainly for colours unsuited for fresco such as azurite, but also metal leaf and pastiglia applications, which will be examined in the following sections.

\section{Polished stucco}

A very peculiar painting technique was developed by Giotto in the Arena chapel in Padua to imitate marble slabs (Fig. 10). The issue of what exactly this technique consisted of has led to a broad discussion on whether Giotto restored

Fig. 10 Polished stucco. Padua, Arena chapel (Photo (c) Creative Commons)

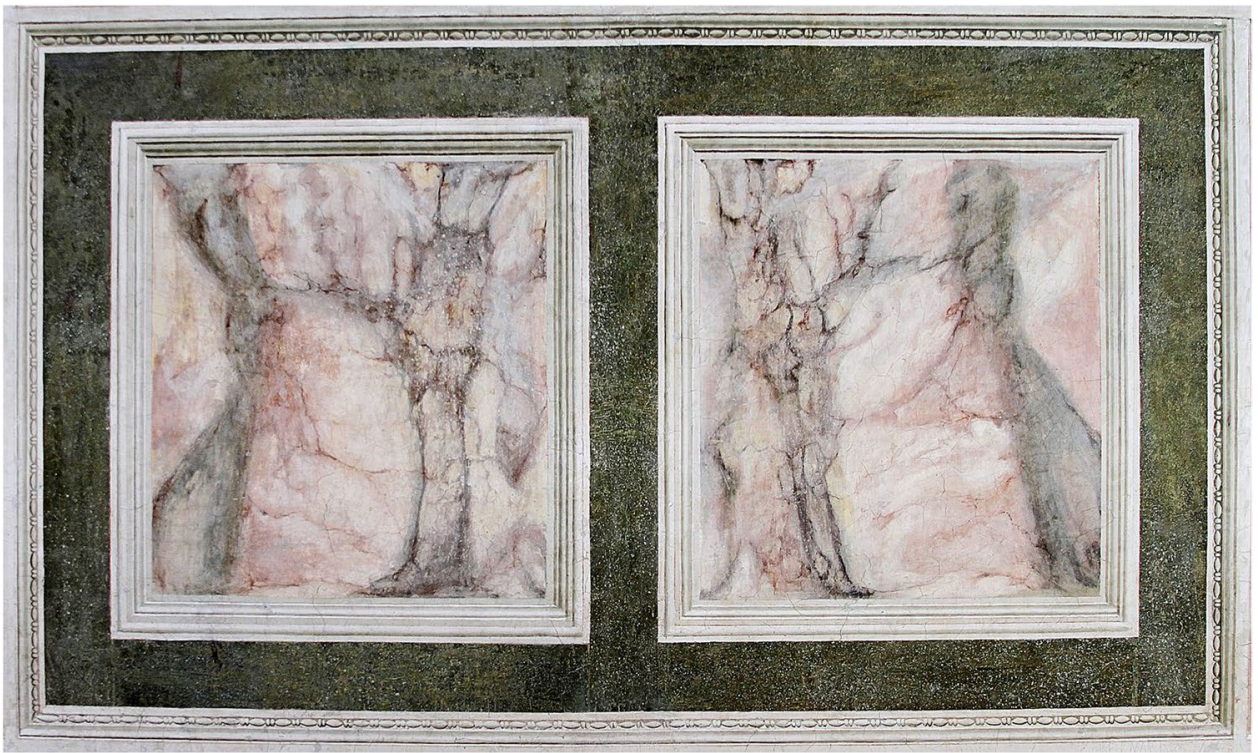


the ancient Roman technique of reproducing marble slabs in fresco, sometimes inaccurately referred to as 'polished Roman stucco'. We know from the study of Roman wall painting that the debated Vitruvian politiones, to which the author dedicates book seven of his De Architectura, referred to the procedure of polishing the painted surfaces, and maybe also to the substances used in the outermost layer that allowed for the smoothing of the plaster. The peculiar reflective and dense effect could be obtained either by adding clay to the final layer of plaster or in the pigments, thus facilitating subsequent polishing operations, or by the addition of spatic calcite giving body to the mortar (Bianchetti et al. 1990; Daniele and Gratziu 1996; Daniele 2000). The crystalline structure of the calcite made it possible, when the plaster was crushed with the trowel, for the faces of the crystals to be arranged coplanar with each other, creating a compact surface, which better tolerated the pressure of the crushing and polishing operations (Guglielmi and Capanna 2005).

Examinations undertaken on several case studies have revealed the existence of a number of technical variants, which nonetheless implied similar procedures, consisting of sequences of superimposed layers. When the mortar was almost but not yet completely dry, a thin layer of plaster (2 to $3 \mathrm{~mm}$ in thickness) was applied, obtained from a finergrained agglomerate and containing a larger quantity of slaked lime. On this layer paint was applied, using very finely ground pigments to avoid spots and scratches. Smoothing was carried out when the plaster was partially dry, using tools similar to irons heated by the fire of burning braziers (Guglielmi and Capanna 2005). In the Arena Chapel, where this technique was employed on large surfaces, microscope examination and mineralogical comparison of thin sections taken both from the fictive marbles and from other areas of the fresco cycle revealed that the marbles contain a higher percentage of binder, i.e. lime, than silica sand (Bianchetti 2005). This artifice allows for more plastic processing and is better suited for final smoothing. In fact, the fictive marbles show evident signs of pressing (Guglielmi and Capanna 2005).

\section{Materials}

The range of materials used to produce wall paintings in the Middle Ages was extremely rich and testifies to the technical ingenuity of medieval artists but also to wider phenomena, including the circulation of knowledge, techniques, materials in the medieval world, between Europe, the Mediterranean, Africa and Asia. While it would not be possible to provide a complete overview here, still it is worth, in our opinion, mentioning at least some essential data, in order to set a general framework.

\section{Arriccio and intonaco}

The composition and proportions of the plaster varied from place to place, but always comprised slaked lime and an inert filles such as sand or ground marble. Sometimes straw could be added to the arriccio and tow to the plaster, in order to keep them wet for longer and facilitate the process of carbonation (Maltese 2019). Such procedure was adopted mainly in the Mediterranean and in Byzantine regions, but also in Europe, for example in the Crucifixion painted in the Chapter House of the church of San Domenico in Pistoia, Tuscany, from the mid-thirteenth century (Maltese 2019). In some cases, for instance in the Arena Chapel in Padua, ground brick was added to the arriccio, again to increase its hydraulic property (Bianchetti 2005).

\section{Pigments}

The range of pigments that could be used for a fresco paint was generally limited to the inorganic ones, since they can cope the alkaline environment of the lime (Artists' pigments, 1986-2007). Fresco colours included yellow and red ochres (Mady et al. 2006), such as sienna, from Italian 'Terra di Siena' literally meaning 'Siena earth', an earth pigment that contains iron oxide and manganese oxide, which was used in two versions: in its natural state, called raw sienna, with a yellowish brown hue, and heated, called burnt or dark sienna, when it becomes a reddish brown (Cornell and Schwertmann 2006; Mastrotheodoros et al. 2021); Naples yellow (Dik 2003; Agresti et al. 2016; Gliozzo and Ionescu 2021); bianco San Giovanni, obtained from dried lime reduced to powder and then dipped in water-a procedure described in details by Cennino (Zanardi et al. 1984; Baroni 1998; Cennini 2012, 2015); vine black, a finely ground material obtained by carbonising vine lees, twigs or stalks (Winter 1983); ivory black, obtained from carbonising ivory, and similar to bone black, which is obtained from carbonising bones instead (Winter 1983); green earth, prepared from the minerals glauconite and/or celadonite (Moretto et al. 2011); finally, Egyptian blue, which is one of the oldests known artificial pigment, already in use since the early dynasties of ancient Egypt, consisting of an artificial copper calcium silicate prepared by heating a mixture of a calcium compound, copper compound and quartz (Uda et al. 2000; Gaetani et al. 2004; Nicola et al. 2018; Švarcová et al. 2021).

Other colours could not withstand the alkaline environment of the lime, and were therefore more often used in $a$ secco paint, bound in organic media as egg or oil. The range includes a few organic pigments (Aceto 2021) and some inorganic pigments such as lead white, a basic lead carbonate, and red lead (Gonzalez et al. 2016; Gliozzo and Ionescu 2021); arsenic-based pigments such as realgar and orpiment (Gliozzo and Burgio 2021); cinnabar, a mercury sulphide 
which is bright red, and could be mixed with white to give a pink flesh colour (Thompson jr 1933; Spring and Grout 2002; Gliozzo 2021); ultramarine, an expensive blue pigment prepared from the mineral lapis lazuli (Gaetani et al. 2004; Osticioli et al. 2009; Favaro et al. 2012); azurite, a natural blue pigment cheaper than ultramarine, obtained by this copper carbonate hydroxide natural mineral (Dei 1998; Bucklow 2013; Švarcová et al. 2021); malachite, a pigment obtained from this natural green copper carbonate hydroxide, which was sometimes also used in a fresco paint without organic binders (Solomon et al. 2011; Švarcová et al. 2021).

\section{Surface embellishments}

Throughout medieval Europe, wall paintings were often dressed with an array of embellishments, adding real materials to the surface of pictures (Fig. 11a). Surface embellishments include a variety of materials such as glass inserts, pastiglia and metal foils (Conti 1986).

Effulgent light effects and surface enrichments were central to the aesthetic of Romanesque and Gothic painting, and a number of elaborate techniques are indeed noted by several authors of artistic treatises. Glass inserts has been added to the wall paintings starting from at least the twelfth century, becoming more popular in the fourteenth. Sometimes reflective materials such as tiny mirrors were also used to increase the luminous effect of the painted surface and move the viewers, as in the Lower Church of St Francis of Assisi (Monciatti 2002) and probably in the frescoes by Giotto in Padua Council Hall (Mariani Canova 1998).

The practice of gilding in painting is mentioned in treatises from antiquity onwards. The recipes and instructions provided by these sources have been verified by scientific investigations (Matteini and Moles 1990). According to Theophilus and Cennino, four types of metal foils were used: gold, gold on tin, tin and silver gilt (Cennini 2012, 2015; Speer 2014). They suggested to employ pure gold to prepare gold foils, which-according to the examinations undertaken thus far-always have a homogeneous thickness between 1.2 and $1.8 \mu \mathrm{m}$ (Merzenich 1996; Travaini 2005). Theophilus devoted an entire chapter of his treatise to the preparation of gold leaf, describing a very demanding procedure which implied that the beaten gold was first laid out in separate sheets of parchment and then beaten again to make thinner and thinner sheets. During the Middle Ages, this procedure was carried out by specialised craftsmen known as battiloro (literally 'gold beaters'), who then supplied painters with the ready-made material (Merzenich 1996). It has been shown that in fourteenth-century Tuscan paintings the metal leaf weighs approximately $0.035 \mathrm{~g}$ and usually has a maximum size of $7.3 \mathrm{~cm}^{2}$ (Merzenich 1996; Travaini 2005). In the Arena Chapel, tin, silver and gold are used by Giotto with different application techniques to give the surfaces varying luminous effects. Apparently, pure gold is always used for Christ's halo, while those of the angels, saints and apostles are decorated either with pure gold or with other metals. In some areas, for example in the Resurrection of Lazarus, Giotto was able to achieve volumetric and optical effects by adding painting onto the gold leaf. He uses tin foil, today blackened due to the natural process of oxidation, to simulate the soldiers' armatures or other metal components-a practice which was commonly adopted throughout the fourteenth and fifteenth centuries. The halo of Christ on the counter façade of the chapel is decorated with three convex mirrors made of glass and lead foil, inserted into the mortar while it was still wet (Capanna and Guglielmi 2005, p 55; Marabelli et al. 2005b). Similar multi-material embellishments were also added to the painted surface of the Maestà frescoed by Simone Martini in the Palazzo Pubblico in Siena, Tuscany; the brooch of the Virgin Mary's lavishly decorated dress, for instance, is made of rock crystal embedded into the plaster (Fig. 11b) (Bagnoli 1999; Leone De Castris 2007).

Pastiglia is found in Catalan and Sienese painting in the early thirteenth century, and also in the German Zackenstil as, for example, in the wall painting of the Bishop's Chapel in Gurk Cathedral, on which rich plastic ornamentation was used on the haloes, brooches, the hems of the robes, but also on the framing areas (Santner 2012). The methods described in the treatises, and in particular in Cennino's Libro dell'arte, can be discerned in Giotto's paintings. In the Arena Chapel, the haloes in pastiglia are made with the same mortar used for the intonachino. The stars on the vault, on the other hand, consists of a more fluid mortar, and were shaped with a matrix (Capanna and Guglielmi 2005). The use of matrices, and moulds to make ornamental elements in raised gesso is also attested in other fresco cycles of the period, for example in the private chapel of the Carrara in their palace in Padua, where crowns and brooches are clearly obtained from moulds (Murat 2016). In addition, punches with floral or geometric shapes were often used to impress patterns on raised gesso, then covered with metal leaf (Fig. 11c).

\section{Technical, material and stylistic developments}

The summary that follows is designed as a synthesis of the above-mentioned aspects and is intended as a critical conflation of existing literature, textual information from art treatises and evidence from technical examinations.

The most significant changes in wall painting techniques during the Middle Ages concern the material, formal andabove all-the stylistic qualities of painting, which changed radically. 
Fig. 11 Examples of surface embellishments, including diverse metal foils used to decorate the soldiers' weapons and armours, together with the trappings of the horses (Padua, Basilica del Santo, Chapel of St James; detail from Altichiero's the Battle of Clavigo (a)); the brooch of the Virgin Mary's dress obtained by embedding rock crystal into the plaster (Siena, Palazzo Pubblico; detail from Simone Martini's Maestà (b)); ornamental patterns obtained by pressing a punch on the raised gesso (Siena, Palazzo Pubblico; detail from Simone Martini's Maestà (c)) (Photos (C) Author; Bagnoli 1999)

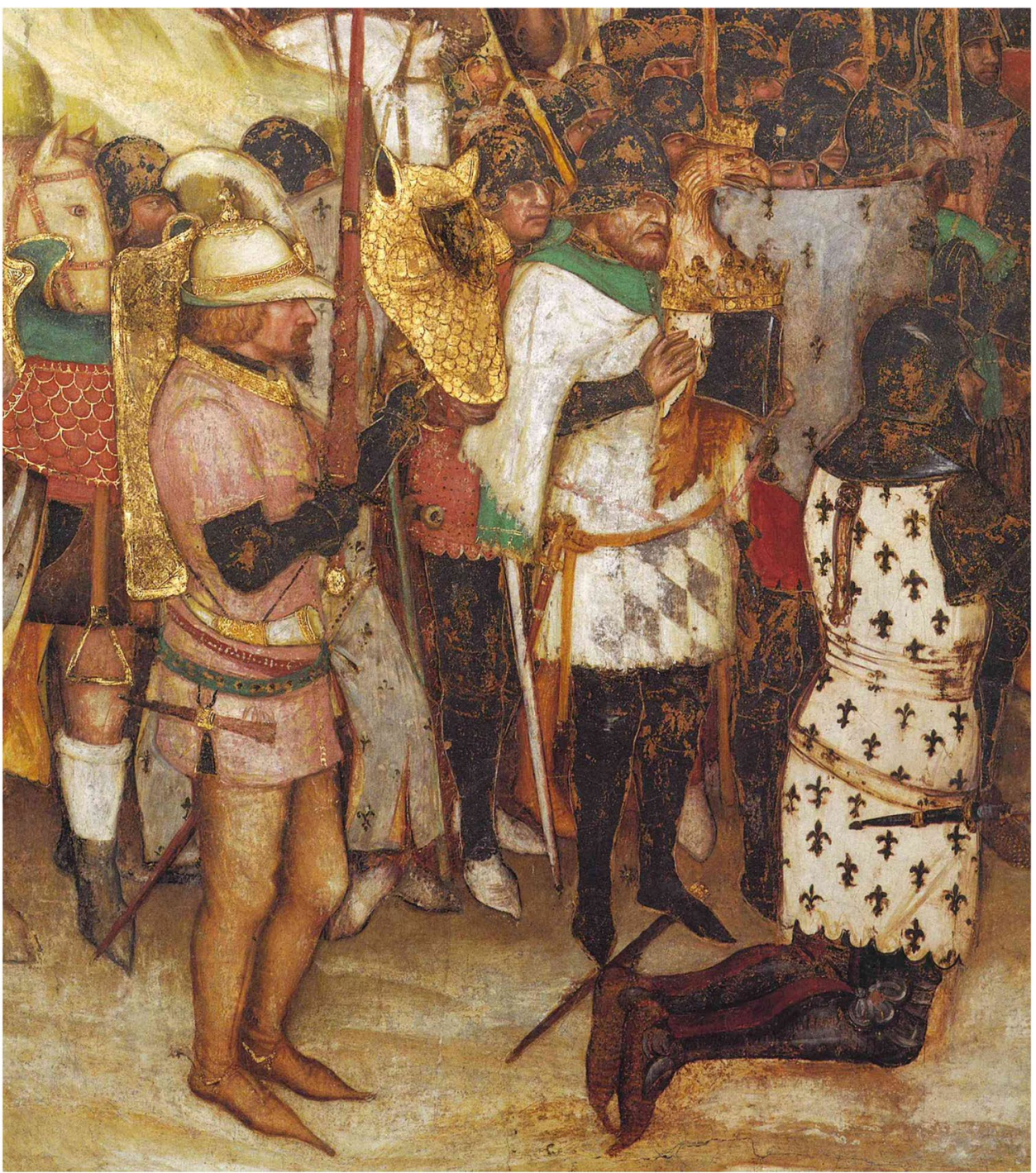

a
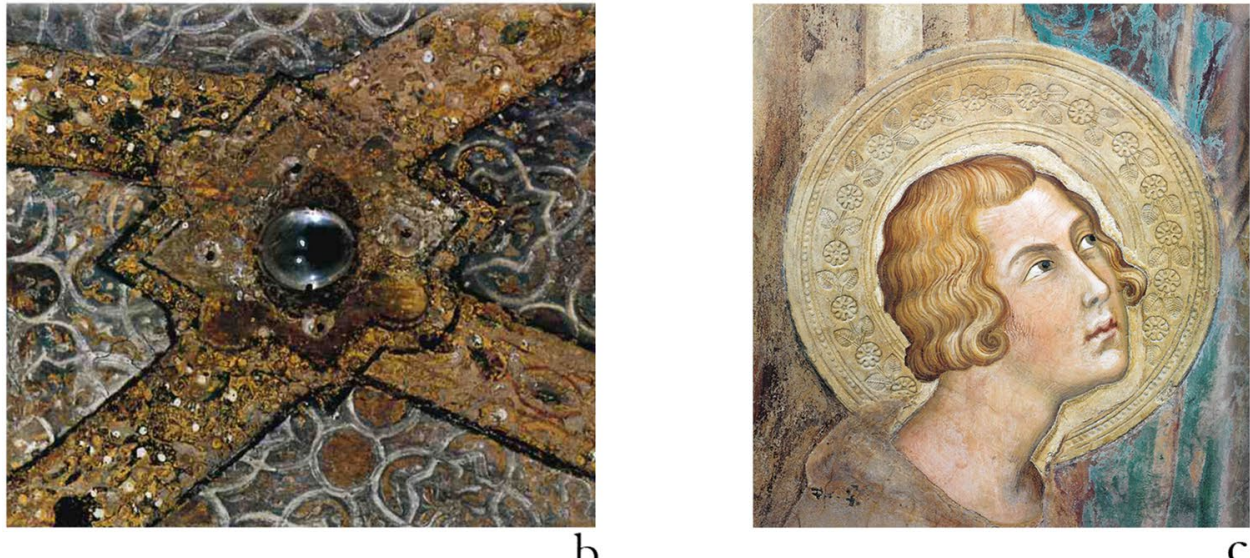

C
It seems that, compared to the Roman wall painting tradition, the number and thickness of the preparatory layers was smaller in the early Middle Ages: in the pictorial decorations of early Christian catacombs in Rome and Viterbo (Lazio region, Central Italy), for instance, the fresco technique was slightly simplified, with fewer 
preparatory layers of plaster (just two instead of the six prescribed by Vitruvius); the plaster was no longer smoothed, and in fact the pictorial surface appears quite rough and irregular (Bisconti 2011, 2017, 2019; Giuliani 2016; Rutgers 2017).

In principle, and as far as is known today, this simplified procedure continued for the first centuries of the Middle Ages, until ca. the tenth century. The most important and best-preserved examples from these dates show the persistence of Late Antique tradition of fresco technique, with methods mediated by Byzantium: a smaller number of preparatory layers, pontate system of applying the intonaco, traces of sinopia on the arriccio, and few incised lines on the wet plaster used to outline geometric patterns of the decoration or ornamental details such as the haloes. Surviving cycles from this period, which testify to the procedures described in coeval treatises, include paintings in the church of S. Maria Antiqua in Rome (different campaigns from the mid-sixth to the ninth century; Andaloro et al. 2016), S. Salvatore in Brescia, in Lombardy, Italy (commissioned by the Lombard king Desiderius and his wife Ansa, decorated with frescoes in the late 750s or 760s; Brogiolo et al. 2010;
Brogiolo 2019), S. Maria foris portas in Castelseprio, near Varese, Lombardy, Italy (Fig. 12a) (which shows a Byzantine background and whose dating is still much debated between the eighth and the tenth centuries; De Marchi 2013; Mitchell and Leal 2013; Brogiolo 2019). North of the Alps, it is worth mentioning the cycles of St John in Müstair, on the shores of Lake Constance in Switzerland (Fig. 12b) (dating back to the Carolingian era; Caroselli et al. 2020; Hueglin et al. 2019; Cavallo et al. 2020), St Georg Oberzell on the Reichenau, Germany (the church was constructed under Abbot Hatto III, 888-913, and the painted decoration dates to the same period; Koshi 1999) and finally the paintings of the crypt of Saint-Germain in Auxerre, France (ninth century; Sapin 1990; Mitchell and Leal 2013). All these cycles show evidence of a secco painting combined with a fresco, with pigments ground in organic binders or calcium hydroxide.

At the same time, it seems that in the Byzantine regions the technique did not change much, with the exception of the more accurate preparation of the support. As suggested by the surviving manuals, none of which predates the end of the sixteenth century (Skovran 1958), straw was often
Fig. 12 Developments of wall painting techniques and style from the early centuries of the Middle Ages to the Romanesque period. Castelseprio, Church of Santa Maria foris portas (a); Müstair, Church of St John (b); Sant'Angelo in Formis, Abbey Church of St Michael (c); Barcelona, Museu Nacional d'Art de Catalunya (d) (detached fresco from Taüll, Church of Sant Climent) (Photos (C) Author; Creative Commons)
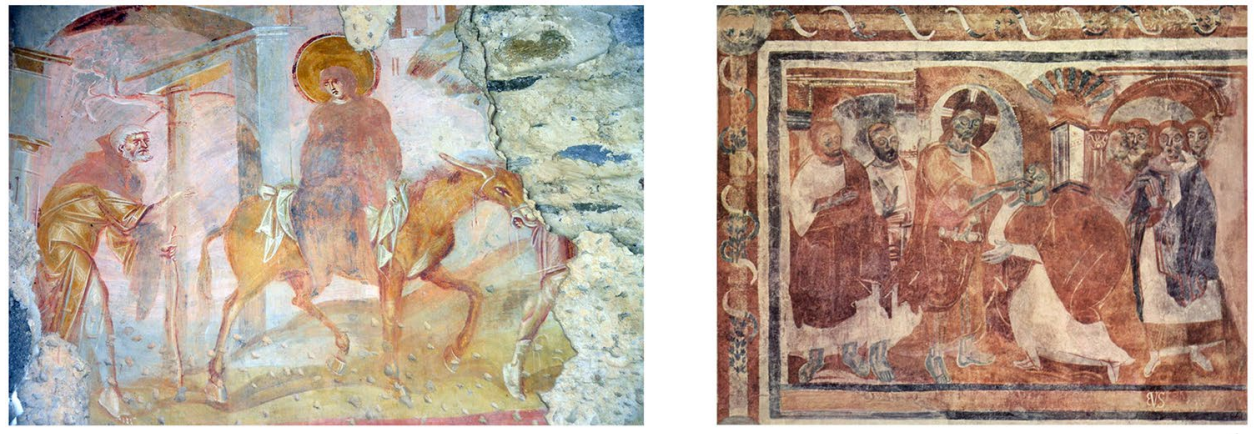

a

$\mathrm{b}$

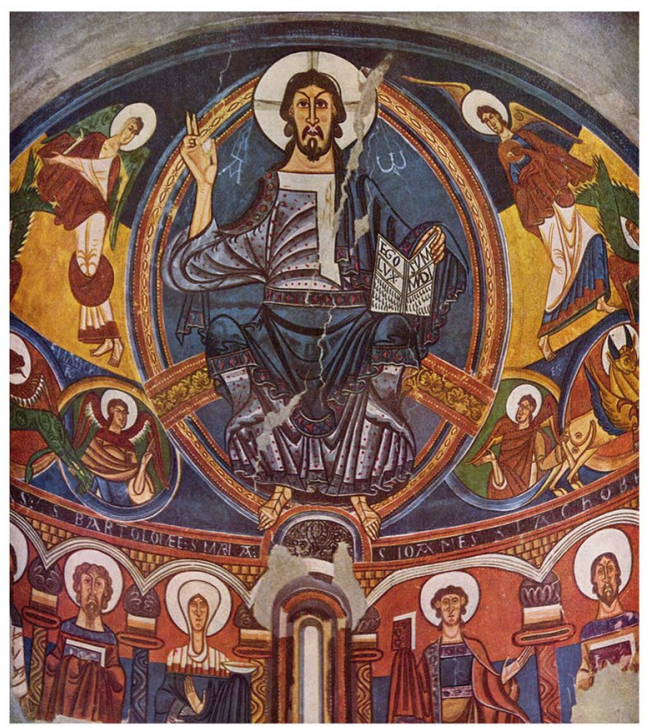

d 
added to the arriccio, along with lime and sand, and tow was added to the plaster to keep the wall wet for longer and facilitate carbonation. The practice of Byzantine wall painting presupposed a rapid execution with large chromatic areas, with minor variatons in the compositional schemes and apparently linked to repeatable forms, as demonstrated by the diffusion among artists of albums of drawings and model books, documented at least from the twelfth century onwards (Lazarev 1966).

As for the Romanesque period (second half of the eleventh century to ca. 1250), evidence survives of $a$ fresco, a secco and mezzo fresco paintings (Fernie et al. 2003). Theophilus, in the only chapter of his De diversis artibus devoted to the subject, clearly mentions the use of lime milk to paint and the most suited methods to apply pigments on an already dry wall. Model books continue to be used, a circumstance which made the preparatory drawing almost unnecessary. Generally speaking, Romanesque wall paintings are characterised by the proliferation of geometric ornamental patterns, bold outlines, parallel drapery folds, surface embellishments in relief gesso, dense and bright palette and rather symmetrical compositions and figures. A large quantity of paintings from this period survives, including Zackenstil frescoes in Germany and Austria (Roehrig Kaufmann 2003; Koch 2013; Grüger 2014), detached cycles from numerous Spanish churches now on display at the Museu Nacional d'Art de Catalunya in Barcelona (Fig. 12d) (Chordá 2012; Company i Climent X, 2016; Pagès i Paretas 2017), and the almost intact cycle in the crypt of the Abbey Church of Saint-Savin-sur-Gartempe in France (Boisseau 2018; Kasperen 2020; Davy 2020). South of the Alps, in the Italian peninsula, many largely intact wall painting programmes are worth mentioning, such as the paintings in the church of Sant'Angelo in Formis, near Caserta (Fig. 12c) (Jacobitti 1992; Duonnolo 2016), the cycle in the church of San Tommaso at Acquanegra sul Chiese, near Mantova (Scirea 2015; Tosatti 2015), the frescoes in crypt of the Basilica in Aquileia, in the FriuliVenezia Giulia region (Dale 1997) and in the crypt of the Cathedral of Anagni, near Frosinone (Gianmaria 2001; Bianchi 2003). Despite regional variations, Romanesque painting has many fundamental features in common and may be regarded as the first truly international medieval style.

The variation marking the transition from Romanesque to Gothic (ca. thirteenth to fifteenth centuries) wall painting consists primarily in innovations in style, technique, function, purpose, contents and audience of art (Kidson et al 2003). Gothic style advances new methods and canons of visual communication, including fresh mimetic idioms, new forms of naturalism and imitative techniques. Narrative was also an increasingly prominent concern, generally associated with emotional imagery meant at establishing a new empathetic relationship with the viewer; the
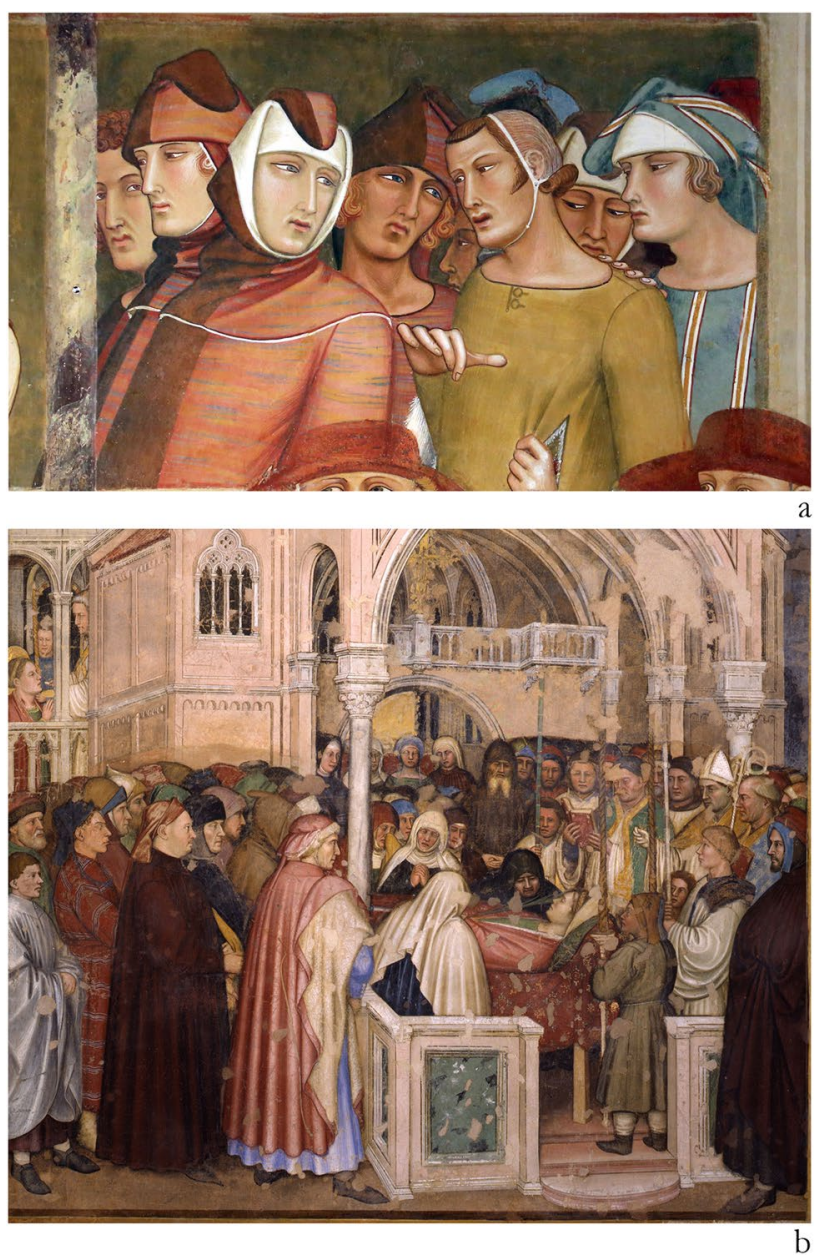

Fig. 13 Gothic wall paintings. Siena, Basilica of St Francis, detail from Ambrogio Lorenzetti's St Louis of Toulouse Makes his Religious Profession amid the Friars (a); Padua, Oratory of St George, detail from Altichiero's Funerals of St Lucy (b) (Photos (c) Creative Commons; Author)

characters' gestures, facial expressions and attitudes were increasingly emphasised in order to enhance the anecdotal features of the events (Figs. 13a, b). These developments corresponded to the emergence and consolidation of intellectual and spiritual currents associated both with religious orders and new forms of lay, civic or family-based, patronage. The study of nature, and of the phenomena of refraction and reception of light, was the basis of the new focus on perspective. Not the linear, geometric-mathematical approach of modern perspective, however, which would only develop during the Renaissance, but the atmospheric approach, which began with Giotto. To satisfy these new demands, Giotto also conducted a technical study of materials: in the Arena Chapel, he combined white lead with oil to obtain a warmer colour than white lime (on lead-based white: Gliozzo and Ionescu 2021). The chromatic diversity is exploited in a spatial sense: in the episode of Joachim 
among the Shepherds, the sheeps in the foreground are painted with San Giovanni white, and appear sharp as if illuminated by the light, while those in the background are executed with white lead combined with oil, thus in a soft, less bright, slightly more yellowish nuance, which creates the illusion of depth (Fernetti 2005).

At the same time, working practices and workshop procedures also changed. The position and role of the artists in society improved. In addition, with the shift from oral to written culture, and increased practices of formalising in written forms the relations between patrons and painters, the quantity of textual information and archival records on the execution of artistic projects and artists became more and more common starting from the thirteenth century onward. Painters, and artists in general, are no longer nameless, unknown authors; on the contrary, starting from this period, evidence of their identity, names, places of origin, lives and careers, multiplied.

In this period, regional differentiations tended to become more evident. North of the Alps, panel and wall painting techniques drew closer together, both in the way painting was applied and in the range of media and pigments used. Tempera and oil started to be used quite frequently in wall painting. Painting in oil on wall was mentioned as early as the eighth century, when Eraclius describes the technique in his De coloribus et artibus Romanorum; Cennino discusses this practice as well, adding that it was most practiced in Germany. The earliest known records of wall paintings in oil dates from 1274 to 1277 and is referred to the King's chamber in Westminster Palace in London; oil was certainly used also for the fresco decoration of Ely Cathedral (1325-1358) where, according to documents, the medium was employed to ground hues (Eastlake 1960). On the contrary, in the Italian peninsula preference was assigned to a fresco technique. The giornata method of fresco preparation became the most widely adopted.

The new painting projects of the thirteenth and fourteenth centuries, often promoted by the mendicant orders, but also by the emerging Signorie and Monarchies, gave artists the opportunity to experiment on a grand scale, with the introduction of fresh iconographies and the developments of new techniques and tools. The Basilica of St Francis in Assisi, where numerous painting workshops were involved (including the so-called 'Maestro oltremontano', the Maestro di san Francesco, Cimabue, Jacopo Torriti, Giotto, Simone Martini, Pietro Lorenzetti, together with their workshops and assistants) is paradigmatic of the changes introduced, as well as of the experimental climate of the last decades of the Middle Ages (Zanardi 1996, 2002; Bonsanti 2002; Cooper and Robson 2013). Palaces and courts, including the papal residences in Rome and Avignon, where Simone Martini, Matteo Giovannetti and numerous assistant painters worked together for quite a long period of time (Castelnuovo 1991;
Castelfranchi Vegas 2003; Bolgia 2020), the private chapels of wealthy families, and new Saints' Shrines, became training grounds for experimentation.

In the late fourteenth century, a new artistic trend emerged, known as International Gothic Style (ca. 1380-ca. 1440). International Gothic paintings are lyrical and majestic in mood, often extravagant, refined and mannered, with a close attention to detail and ornamentations. Wall paintings are decorated with large quantities of precious surface embellishments (Fig. 14a), and are frequently finished in $a$ secco paint with the inclusion of bright tempera pigments and lakes. According to a trend already seen in respect to model books and pattern repertoires, natural details, flowers, plants studied from real prototypes are often included (Fig. 14b) to create background and settings for the events; they could also have additional moral and/or spiritual meanings. The stylistic trend, which was mainly the product of secular court culture, was widespread all over Europe, although regional variations obviously existed. In fact, in the
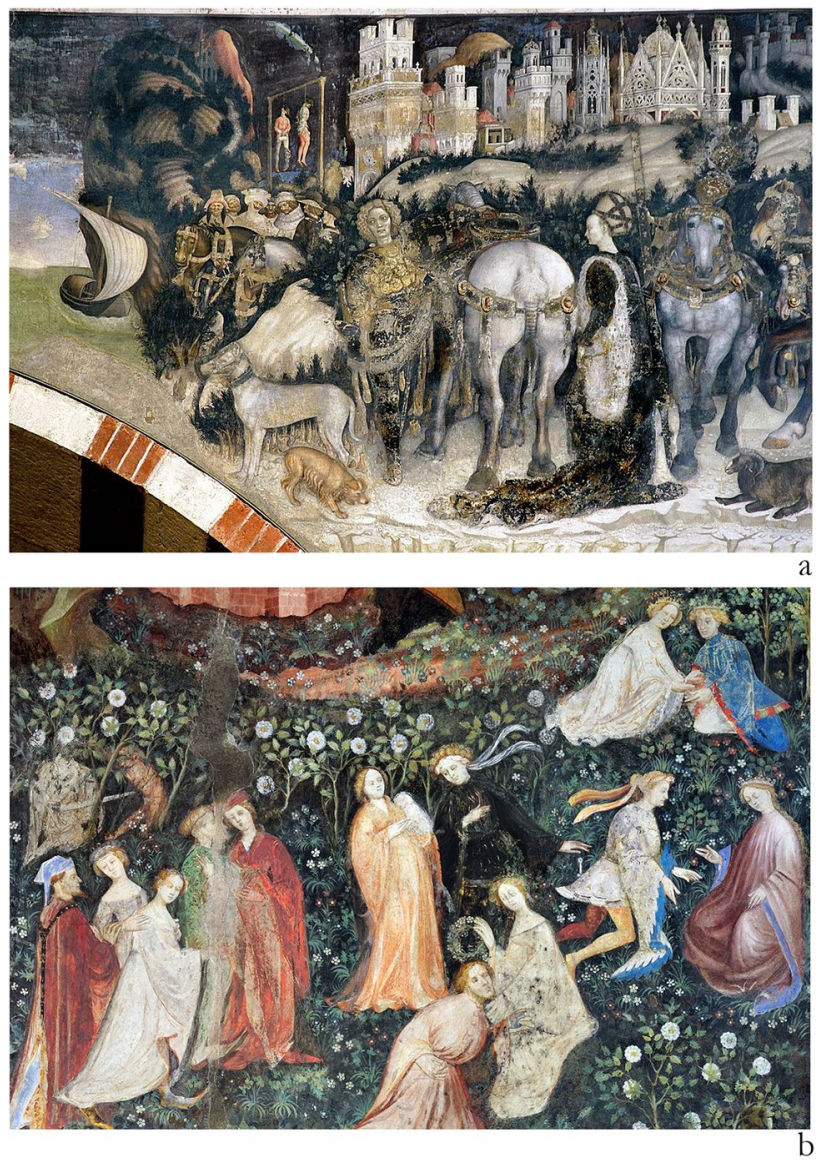

Fig. 14 International Gothic wall paintings. Verona, Church of St Anastasia, Pellegrini Chapel, detail from Pisanello's St. George and the Princess (a); Trento, Buonconsiglio Castle, Torre Aquila, detail from Master Venceslao's Cycle of Month (b) (Photos (C) Creative Commons; Author) 
thirteenth and fourteenth centuries courts at Paris, London, Milan and Avignon witnessed a rapid circulation of ideas and artistic forms between them, fostered by the emergence of art collections and libraries in late fourteenth century, and by inter-dynastic alliances.

\section{Concluding remarks}

It goes without saying, wall paintings should be set against a wider background, avoiding any rigid taxonomy between artistic forms, media and techniques. As an integral part of the period's visual culture, medieval wall paintings shall indeed be examined in parallel to wider social, cultural, spiritual phenomena. What is more, immaterial culture, performances, customary practices also need to be considered. In fact, wall paintings formed integral part of their contextual environment, and as such ceremonies and rituals performed within these spaces, but also the connections that wall paintings established with other artistic forms (the music played in the same environments, for instance), need to be examined in parallel to the technical, stylistic, material investigation of the paintings. In addition, as scholars have extensively demonstrated, the audience's response should be taken into careful consideration in order to grasp the real meanings given to wall paintings in the past, not to mention the crucial part played by the patrons.

While this article is mainly committed to technical aspects, and maintains wall paintings as its core of investigation, still it is crucial to point out, in conclusion, that only a critical conflation of diverse methodologies and research tools, and the parallel examination of matters related to intention, reception, production, as well as to social, cultural, ideological aspects, can lead to a deep understanding of wall painting through the ages, of the reasons behind its evolution(s) and its long duration.

Funding Open access funding provided by Università degli Studi di Padova within the CRUI-CARE Agreement.

Data availability Data sharing is not applicable to this article as no new data were created or analysed in this study.

\section{Declarations}

Conflict of interest The author declares that there is no conflict of interest.

Open Access This article is licensed under a Creative Commons Attribution 4.0 International License, which permits use, sharing, adaptation, distribution and reproduction in any medium or format, as long as you give appropriate credit to the original author(s) and the source, provide a link to the Creative Commons licence, and indicate if changes were made. The images or other third party material in this article are included in the article's Creative Commons licence, unless indicated otherwise in a credit line to the material. If material is not included in the article's Creative Commons licence and your intended use is not permitted by statutory regulation or exceeds the permitted use, you will need to obtain permission directly from the copyright holder. To view a copy of this licence, visit http://creativecommons.org/licenses/by/4.0/.

\section{References}

Aceto M (2021) The palette of organic colourants in wall paintings. Archaeological and Anthropological Sciences. https://doi.org/ 10.1007/s12520-021-01392-3

Agresti G, Baraldi P, Pelosi C, Santamaria U (2016) Yellow pigments based on lead, tin, and antimony: ancient recipes, synthesis, characterization, and hue choice in artworks. Color Res Appl 41:226-231. https://doi.org/10.1002/col.22026

Aldrovandi A (2006) Il 'Taccuino' di Giovannino de' Grassi della Biblioteca Civica di Bergamo: tecnica di esecuzione e restauro. In: Frosinini C, I materiali cartacei. Centro Di, Florence, pp 19-51

Andaloro M, Bordi G, Morganti G (2016) Santa Maria Antiqua tra Roma e Bisanzio. Electa, Milan

Arizzi A, Cultrone G (2021) Mortars and plasters - How to characterise hydraulic mortars. Archaeological and Anthropological Sciences. https://doi.org/10.1007/s12520-021-01404-2

Artists' pigments (1986-2007). A handbook of their history and characteristics. 4 vols. Archetype, London

Augusti S (1959) Sui colori degli antichi: la chrysocolla. Rendiconti dell'Accademia di Archeologia, Lettere e Belle Arti di Napoli 34:7-13

Bagnoli A (1999) La Maestà di Simone Martini. Silvana Editoriale, Milan

Barnes CF (2009) The Portfolio of Villard de Honnecourt (Paris, Bibliothèque Nationale de France, MS Fr 19093). New critical edition and color facsimile. Ashgate, Burlington

Baroni S (1998) 'Riducendoti al triare de' colori'. Prescrizioni sui colori nel Libro dell'Arte di Cennino Cennini. ACME - Annali della Facoltà di Lettere e Filosofia dell'Università degli Studi di Milano 51:53-64

Baroni S (2013) Mappae clavicula: alle origini dell'alchimia in Occidente; testo, traduzione, note. Il Prato, Saonara

Basile G (2005) (ed) Giotto nella cappella Scrovegni: materiali per la tecnica pittorica. Studi e ricerche dell'Istituto Centrale per il Restauro. Bollettino d'Arte - Monographic issue

Becker H (2021) Pigment nomenclature in the ancient Near East, Greece, and Rome. Archaeological and Anthropological Sciences. https://doi.org/10.1007/s12520-021-01394-1

Bensi P (1978-1979) La tavolozza di Cennino Cennini. Studi di storia delle arti, pp 37-85

Bianchetti PL (2005) L'intonaco di preparazione e di finitura del ciclo pittorico di Giotto nella Cappella degli Scrovegni. In: Basile G (ed) Giotto nella cappella Scrovegni: materiali per la tecnica pittorica. Studi e ricerche dell'Istituto Centrale per il Restauro. Bollettino d'Arte - Monographic issue, pp 5-16

Bianchetti PL, Campisi M, Gratziu C, Melucco Vaccaro A (1990) La calcite spatica dell'intonaco romano. In: Superfici dell'architettura: le finiture. Atti del Convegno di Studi di Bressanone. Libreria Progetto, Padova, pp 251-260

Bianchi A (2003) Il restauro della cripta di Anagni. Artemide, Rome

Biotti A (2018) La figura di Cennino Cennini pittore nella letteratura critica recente. Miscellanea storica della Valdelsa, $123 / 1-2: 157-178$ 
Bisconti F (2011) Le pitture delle catacombe romane: restauri e interpretazioni. Tau Ed., Todi

Bisconti F (2017) Catacombe di Domitilla: restauri nel tempo. Pontificio Istituto di Archeologia sacra, Città del Vaticano

Bisconti F (2019) Pitture paleocristiane delle catacombe del territorio viterbese. In: Ceci F, Fiocchi Nicolai V, Pastura G (eds), Le catacombe della Tuscia viterbese. Contributo alla storia del territorio nella tarda antichità e nell'alto medioevo. Spolia Edizioni, Fregene, pp 91-109

Boisseau C (2018) Les peintures de la chapelle axiale de Saint-Savinsur-Gartempe: les résultats de l'approche archéographique. Revue historique du Centre-Ouest 16:7-25

Bolgia C (2020) Patrons and artists on the move: new light on Matteo Giovannetti between Avignon and Rome. Papers of the British School at Rome 88:185-213

Bolland A (1996) Art and Humanism in Early Renaissance Padua: Cennini, Vergerio and Petrarch on Imitation. Renaiss Q 49:469-487

Boltz von Ruffach, V (1549) Illuminierbuch, wie man allerlei Farben bereiten, mischen, und aufragen soll, hrsg. von CJ Benziger, Munich, Georg D.W. Callewey

Bosanti G (2002) (ed) La Basilica di San Francesco ad Assisi. 4 vols. Franco Cosimo Panini, Modena

Bork R (2011) Villard's Laon Tower drawings and the visual transmission of architectural ideas. In: Bork R, Clark WW, McGehee A (eds) New approaches to medieval architecture. Farnham: Surrey, pp 159-167

Boskovits M (1973) Cennino Cennini. Pittore nonconformista. Mitteilungen des Kunsthistorischen Instituts in Florenz 17:29-50

Borgiolo GP, Gheroldi V, Ibsen M, Mitchell J (2010) Ulteriori ricerche sul San Salvatore di Brescia. Hortus Artium Medievalium 16:209-232

Brogiolo GP (2019) San Salvatore di Brescia e Santa Maria foris portas di Castelseprio: sequenze e datazioni. In: Lambert C, Pastore F (eds) Convegno nazionale di studi 'Erat hoc sane mirabile in regno Langobardorum'. Insediamenti montani e rurali nell'Italia longobarda, alla luce degli ultimi studi. Arci Postiglione, Salerno, pp 45-62

Bucher F (1977) A rediscovered tracing by Villard de Honnecourt. Art Bulletin 59:315-319

Bucklow S (2013) Processes and pigment recipes: azurite. Bulletin of the Hamilton Kerr Institute 4:95-103

Bulatkin E (1954) The Spanish word 'Matiz' in the technical vocabulary of mediaeval painters. Traditio 10:459-527

Burgio L (2021) Pigments, dyes and inks - their analysis on manuscripts, scrolls and papyri. Archaeological and Anthropological Sciences. https://doi.org/10.1007/s12520-021-01403-3

Burns T (2017) Compositiones variae: a late eight-century craftsman's technical treatise reconsidered. Archetype, London

Caffaro A (2000) Teofilo monaco. Le varie arti. De diversis artibus. Manuale di tecnica artistica medievale. Palladio, Salerno

Caffaro A (2003) Scrivere in oro. Ricettari medievali d'arte e artigianato (secoli IX-XI). Codici di Lucca e Ivrea. Liguori Editore, Naples

Caleca A (1979) Pisa: Museo delle Sinopie del Camposanto Monumentale. Opera della Primaziale Pisana, Pisa

Capanna F, Guglielmi A (2005) Osservazioni relative alla tecnica di esecuzione dei dipinti murali nella cappella, effettuate durante il cantiere di restauro. In: Basile G (ed) Giotto nella cappella Scrovegni: materiali per la tecnica pittorica. Studi e ricerche dell'Istituto Centrale per il Restauro. Bollettino d'Arte - Monographic issue, pp 47-72

Caroselli M, Hajdas I, Cassitti P (2020) Radiocarbon dating of dolomitic mortars from the convent Saint John, Müstair (Switzerland): first results. Radiocarbon 62:601-615

Caroselli M, Ruffolo SA, Piqué F (2021) Mortars and plasters - How to manage mortars and plasters conservation.
Archaeological and Anthropological Sciences. https://doi.org/ 10.1007/s12520-021-01409-X

Castelfranchi Vegas L (2003) L'esperienza internazionale di Avignone. In: Carbonelli E, Cassanelli R, VElmas T (eds) Il Rinascimento in oriente e occidente, 1250-1490. Jaca Book, Milan, pp 98-107

Castelnuovo E (1991) Un pittore italiano alla corte di Avignone: Matteo Giovannetti e la pittura in Provenza nel secolo XIV. Einaudi, Turin

Cavallo G, Aceto M, Emmenegger R, Keller AT, Lenz R, Villa L, Wörz S, Cassitti, P (2020) Preliminary non-invasive study of Carolingian pigments in the churches of St. John at Müstair and St. Benedict at Malles. Archaeological and anthropological sciences 12/73:1-20

Cavallo G, Riccardi MP (2021) Glass-based pigments in painting. Archaeological and Anthropological Sciences (forthcoming).

Cennino Cennini (2012) Il libro dell'arte, 7th edn. Frezzato F ed. Neri Pozza, Vicenza

Cennini C (2015) Cennino Cennini's 'Il libro dell'arte': a new English translation and commentary with Italian transcription. Archetype, London

Chordá F (2012) El ábside de Sant Climent de Taüll. Casimiro, Madrid

Clarke M (2001) The art of all colours Medieval recipe books for painters and illuminators. Archetype, London

Clarke M (2013) The earliest technical recipes: Assyrian recipes, Greek chemical treatises and the 'Mappae Clavicula' text family. In: Córdoba R (ed) Craft treatises and handbooks. The dissemination of technical knowledge in the Middle Ages. Brepols, Turnhout, pp 9-13

Colalucci G (2003a) Fresco. Grove Art Online. https://www.oxfordarto nline.com/groveart/view/10.1093/gao/9781884446054.001.0001/ oao-9781884446054-e-7000029867? rskey=gfR6AX\&result $=1$. Accessed 30 Jan 2020

Colalucci G (2003b) Lime secco. Grove Art Online. https://www.oxfor dartonline.com/groveart/view/10.1093/gao/9781884446054.001. 0001/oao-9781884446054-e-7000051117\#oao-9781884446054e-7000051117. Accessed 30 Jan 2020

Colalucci G (2003c) Secco. Grove Art Online. https://www.oxfordarto nline.com/groveart/view/10.1093/gao/9781884446054.001.0001/ oao-9781884446054-e-7000077290\#oao-9781884446054-e7000077290. Accessed 30 Jan 2020

Company i Climent X (2016) The pantocrator of Sant Climent de Taüll: the light of Europe. Edicións i Publicacións de la Universitat de Lleida, Lleida

Conti A (1986) Tempera, oro, pittura a fresco: la bottega dei 'primitivi'. In: La pittura in Italia. Il Duecento e il Trecento, II, Milan, Electa, pp 513-528

Conti A (1988) Affresco, pittura a calce, pittura a secco. In: Poso R, Galante R (eds), Tra metodo e ricerca: contributi di storia dell'arte. Congedo, Galatina, pp 159-177

Cooper D, Robson J (2013) The making of Assisi: the Pope, the Franciscans and the paintings of the Basilica. Yale University Press, New Haven

Cordaro M (1991) Affresco. In: Romanini AM (ed) Enciclopedia dell'Arte Medievale, vol. I. Istituto della Enciclopedia Italiana, Rome, pp 158-163

Cornell RM, Schwertmann U (2006) The iron oxides: structure, properties, reactions, occurences and uses. Wiley, e-book

Dale TA (1997) Relics, prayer, and politics in medieval Venetia: romanesque painting in the crypt of Aquileia cathedral. Princeton University Press, Princeton

Daniele D (2000) Gli stucchi della villa ellenistico-romana di Segesta (Casa del Nevarca): studio dei materiali e della tecnica di messa in opera. In: Terze giornate internazionali di studi sull'area Elima. Atti. I. Gibellina, Pisa, pp 327-356

Daniele D, Gratziu C (1996) Marmo e calcite spatica di vena: termini di un equivoco sull'intonaco vitruviano. Annali della Scuola 
Normale Superiore di Pisa - Classe di Lettere e Filosofia, I: 541-548

Davis-Weyer C (1994) Speaking of art in the early Middle Ages: patrons and artists among themselves. In: Testo e immagine nell'Alto Medioevo. CISAM, Spoleto, pp 955-991

Davy C (2020) Les peintures murales de Saint-Jean-Baptiste de Château-Gontier et de Saint-Savin-sur-Gartempe: de la similitude à la dissemblance. In: Angheben M (ed) Les stratégies de la narration dans la peinture médiévale. La représentation de l'Ancien Testament aux IVe-XIIe siècles. Brepols, Turnhout, pp 265-289

Degering H (1928) Theophilus Presbyter qui et Rugerus. In: Degering H, Menn W (eds) Westfälische Studien Alois Böhmer gewindmet. Leipzig, pp 248-262

Dei L (1998) Green degradation products of azurite in wall paintings: identification and conservation treatment. Stud Conserv 43:80-88

DeLaine J (2021) Production, transport and on-site organisation of Roman mortars and plasters. Archaeological and Anthropological Sciences. https://doi.org/10.1007/s12520-021-01401-5

Delle Foglie A (2006) Un taccuino tardogotico lombardo: studi sul 'Libretto degli anacoreti'. Arte lombarda 146/148-2/3:55-62

Delle Foglia A (2019) Il Libretto degli Anacoreti e il Libro di Giusto. De Luca editori d'arte, Rome

De Marchi PM (2013) (ed) Castelseprio e Torba. Sintesi delle ricerche e aggiornamenti. SAP Società Archeologica, San Lorenzo

Del Serra A (1986) Sodoma a Monteoliveto Maggiore e discussioni su tecniche miste, pigmenti e cartoni (ca. 1505-08). In: Borsook E, Superbi Gioffredi F (eds) Tecnica e stile: esempi di pittura murale del Rinascimento italiano, I. Silvana Editoriale, Milan, pp 59-68

Dik, J (2003) Scientific analysis of historical paint and the implications for art history and art conservation. The case studies of Naples yellow and discoloured smalt. Dissertation, University of Amsterdam

Dines I (2013) The Theophilus manuscript tradition reconsidered in the light of new manuscript discoveries. In: Speer A (ed) Zwischen Kunsthandwerk und Kunst: die 'Schedula diversarum artium.' Gruyter, Berlin, pp 3-10

Dodge BK (1978) Tradition, innovation, and technique in Trecento mural paintings: the frescoes and sinopie attributed to Francesco Traini in the Camposanto in Pisa. Dissertation, John Hopkins University

Dodwell CR (1961) The various arts/De diversis artibus. Nelson, London

Domingo Sanz I, Chieli A (2021) Characterising the pigments and paints of prehistoric artists. Archaeological and Anthropological Sciences. https://doi.org/10.1007/s12520-021-01397-y

Duonnolo F (2016) Come un roveto ardente: la teologia visiva della basilica benedettina di Sant'Angelo in Formis. Libreria Editrice Vaticana, Città del Vaticano

Eastlake GL (1960) Method and materials of painting of the great schools and masters. I. Dover, New York

Eclercy B (2007) 'Granare': Zur historischen Terminologie des Goldgrunddekors im Traktat des Cennino Cennini. Mitteilungen des Kunsthistorischen Instituts in Florenz 51(3-4):539-554

Ergenç D, Fort R, Varas-Muriel MJ, Alvarez de Buergo M (2021) Mortars and plasters - how to characterise aerial mortars and plasters. Archaeological and Anthropological Sciences. https:// doi.org/10.1007/s12520-021-01398-x

Evans MW (1969) Medieval drawings. Paul Hamlyn, London

Favaro M, Bianchini S, Guastoni A, Marini F (2012) Characterization of lapis lazuli and corresponding purified pigments for a provenance study of ultramarine pigments used in works of art. Anal Bioanal Chem 402(6):2195-2208

Fernetti F (2005) Considerazioni sulla tipologia delle stesure a secco. In: Basile G (ed) Giotto nella cappella Scrovegni: materiali per la tecnica pittorica. Studi e ricerche dell' Istituto Centrale per il Restauro. Bollettino d'Arte - Special essay, pp 109-120

Fernie E et al. (2003) Romanesque. Grove Art Online. https://www. oxfordartonline.com/groveart/view/10.1093/gao/9781884446 054.001.0001/oao-9781884446054-e-7000072835? rskey= u1KsAE\&result=1\#oao-9781884446054-e-7000072835-div17000072836. Accessed 30 Jan 2020

Ferretti M (1980) Sinopie (e affreschi?): a proposito del nuovo museo di Pisa. Prospettiva 20:2-6

Freise E (1981) Roger von Helmarshausen in seiner monastischen Umwelt. Frühmittelalterliche Studien 15:180-293

Freise E (1985) Zur Person des Theophilus und seiner monastischen Umwelt. In: Legner A (ed) Ornamenta Ecclesiae. Kunst und Künstler der Romanik. Schnütgen-Museum, Köln, pp 357-361

Frison G, Brun G (2018) 'Compositiones Lucenses' and 'Mappae Clavicula': two traditions or one? New evidence from empirical analysis and assessment of the literature. Heritage Science $6: 1-17$

Gaetani MC, Santamaria U, Seccaroni C (2004) The use of Egyptian blue and lapis lazuli in the Middle Ages: the wall paintings of the San Saba Church in Rome. Stud Conserv 49(1):13-22

Garzya Romano C (1996) I colori e le arti dei Romani e la compilazione pseudo-eracliana. Il Mulino, Bologna

Geymonat LV (2012) Drawing, memory and imagination in the Wolfenbüttel Musterbuch. Mediev Encount 18(4-5):518-583

Geymonat LV (2013) Un disegno preparatorio del XIII secolo per un ciclo pittorico sull'Apocalisse. Ikon 6:55-64

Geymonat LV (2016) Carolingian drawings in the Wolfenbüttel Centaur Palimpset. In: Carmassi P (ed) Retter der Antike. Marquard Gude (1635-1689) auf der Suche nach den Klassikern. Harrassowitz Verlag in Kommission, Wiesbaden, pp 309-347

Geymonat LV (2015) Visual memory and a drawing by Villard de Honnecourt. In: Nikulin D (ed) Memory. A history. Oxford University Press, Oxford, pp 125-130

Geymonat LV (2018) Taccuini e disegni di viaggio nel XIII secolo. In: Bilotta MA (ed) Medieval Europe in motion. The circulation of artists, images, patterns and ideas from the Mediterranean to the Atlantic coast $\left(6^{\text {th }}-15^{\text {th }}\right.$ centuries $)$. Officina di Studi Medievali, Palermo, pp 271-280

Gianmaria G (2001) (ed) Un universo di simboli: gli affreschi della cripta nella cattedrale di Anagni. Viella, Rome

Gilbert CE (2003). Giotto (di Bondone). Grove Art Online. https:// www.oxfordartonline.com/groveart/view/10.1093/gao/97818 84446054.001.0001/oao-9781884446054-e-7000032431?rskey= tYUHbU\&result=6\#oao-9781884446054-e-7000032431-div27000032448. Accessed 30 Jan 2020

Giry A (1878) Notice sur un traité du moyen âge intitulé De coloribus et artibus Romanorum. Bibliothèque de l'Ecole des hautes études 35:209-237

Giuliani R (2016) Le catacombe di Priscilla. Pontificia Commissione di Archeologia Sacra, Città del Vaticano

Gliozzo E (2021) Pigments - Mercury-based red (cinnabar-vermilion) and white (calomel) and their degradation products. Archaeological and Anthropological Sciences. https://doi.org/10.1007/ s12520-021-01402-4

Gliozzo E, Ionescu C (2021) Pigments - Lead-based whites, reds, yellows and oranges and their alteration phases. Archaeological and Anthropological Sciences. https://doi.org/10.1007/ s12520-021-01407-z

Gliozzo E, Pizzo A, La Russa MF (2021) Mortars, plasters and pigments - research questions and sampling criteria. Archaeological and Anthropological Sciences. https://doi.org/10.1007/ s12520-021-01393-2

Gliozzo E, Burgio L (2021) Pigments - Arsenic-based yellows and reds. Archaeological and Anthropological Sciences. https://doi. org/10.1007/s12520-021-01431-Z 
Gonzalez V, Calligaro T, Walleza G, Eveno M, Toussaint K, Menu M (2016) Composition and microstructure of the lead white pigment in Masters' paintings using HR Synchrotron XRD. Microchemical Journal 125:43-49

Grüger K (2014) Zu den neu freigelegten Wandmalereien im Zackenstil in St Peter Und Paul in Erfurt. Kunstchronik 67(11):563-570

Guareschi I (1905) Osservazioni sul 'De Arte Illuminandi' e sul Manoscritto bolognese (Secreti per colori) del sec. XV. Atti della Regia Accademia delle Scienze di Torino XL:633-690

Guglielmi A, Capanna F (2005) L'intonaco giottesco per la realizzazione dei finti marmi. Riflessioni e comparazioni sui procedimenti esecutivi. In: Basile G (ed) Giotto nella cappella Scrovegni: materiali per la tecnica pittorica. Studi e ricerche dell'Istituto Centrale per il Restauro. Bollettino d'Arte - Monographic issue, pp 47-72

Halleaux R, Meyvaert P (1987) Les origins de la Mappae clavicula. Archives D'histoire Doctrinale at Littéraire Du Moyen Âge 62:7-58

Hedfords H (1932) Compositiones ad tingenda musiva Herausgegeben ubersetzt und philologisch erklaert. Almquist e Wiksells, Uppsala

Hendrie R (1847) Theophili, qui et Rugerus, presbyteri et monachi libri III. De diversis artibus: seu Diversarum artium schedula. J. Murray, London

Hoeniger C (2003) Wall painting. Grove Art Online. https://www.oxfor dartonline.com/groveart/view/10.1093/gao/9781884446054.001. 0001/oao-9781884446054-e-7000090505? rskey=Xu6r2X\& result $=1$. Accessed 30 Jan 2020

Horak U (1992) Illuminierte Papyri, Pergamene und Papiere, I A Holzhausen, Wien

Hueglin S, Caroselli M, Cassitti P (2019) Tracing technological transformation - mechanical mortar production in early medieval Europe and at Müstair Monastery, Switzerland. STAR: Science and Technology of Archaeological Research 5:305-322

Ilg, A (1874) Theophilus Presbyter, Schedula diversarum atrium. W. Braumüller, Wien

Jacobitti GM (1992) La basilica benedettina di Sant'Angelo in Formis. Edizioni Scientifiche Italiane, Napoli

James MR (1951) Pictor in Carmine. Archaeologia 94:141-166

Jenni U (2000) Taccuino. In: Romanini AM (ed) Enciclopedia dell'Arte Medievale, vol 6. Istituto della Enciclopedia Italiana, Rome, pp $57-61$

Johnson RP (1935) Notes on some manuscripts of the 'Mappae Clavicula'. Speculum X:72-81

Johnson RP (1937) Some continental manuscripts of the 'Mappae Clavicula'. Speculum XII:84-103

Johnson RP (1939) Compositiones variae: from Codex 490, Biblioteca Capirolare, Lucca, Italy. An introductory study. The University of Illinois Press, Urbana

Kasperen S (2020) Genesis cycle: tradition, theology and politics. From Cotton Genesis to Saint-Savin-sur-Gartempe. In: Angheben M (ed) Les stratégies de la narration dans la peinture médiévale. La représentation de l'Ancien Testament aux IVe-XIIe siècles. Brepols, Turnhout, pp 225-264

Kessler HL (1997) Modello. In: Romanini AM (ed) Enciclopedia dell'Arte Medievale, vol 8. Istituto della Enciclopedia Italiana, Rome, pp 491-496

Kidson P et al. (2003) Gothic. Grove Art Online. https://www.oxfor dartonline.com/groveart/view/10.1093/gao/9781884446054. 001.0001/oao-9781884446054-e-7000033435?rskey $=$ sFoxxO\& result=2\#oao-9781884446054-e-7000033435-div1-7000033605. Accessed 30 Jan 2020

Kitzinger E (1960) I mosaici di Monreale. Flaccovio, Palermo

Knapp CW, Christidis GE, Venieri D, Gounaki I, Gibney-Vamvakari J, Stillings M, Photos-Jones E (2021) The ecology and bioactivity of some Greco-Roman medicinal minerals: the case of
Melos earth pigments. Archaeological and Anthropological Sciences. https://doi.org/10.1007/s12520-021-01396-Z

Koch S (2013) Der Zackenstil in der Monumentalmalerei am Niederrhein zwischen 1200 und 1300. Dissertation, University of Heidelberg

Koshi K (1999) Die frühmittelalterlichen Wandmalereien der St. Georgskirche zu Oberzell auf der Bodenseeinsel Reichenau. Deutscher Verlag für Kunstwissenschaft, Berlin

Kroustallis S (2013) The 'Mappae Clavicula' treatise of the 'Codex Matritensis 19' and the transmission of art technology in the Middle Ages. In: Córdoba R (ed) Craft treatises and handbooks. The dissemination of technical knowledge in the Middle Ages. Brepols, Turnhout, pp 69-84

Kroustallis S (2014) Theophilus matters: the Thorny question of the authorship of the 'Schedula diversarum artium.' In: Speer A (ed) Zwischen Kunsthandwerk und Kunst: die 'Schedula diversarum artium.' Gruyter, Berlin, pp 52-71

La Russa MF, Ruffolo SA (2021) Mortars and plasters - How to characterise mortars and plasters degradation. Archaeological and Anthropological Sciences. https://doi.org/10.1007/ s12520-021-01405-1

Lancaster LC (2021) Mortars and plasters - How mortars were made. The Literary Sources. Archaeological and Anthropological Sciences. https://doi.org/10.1007/s12520-021-01395-0

Lazarev V (1966) Old Russian murals and mosaics from the $11^{\text {th }}$ to the $15^{\text {th }}$ century. Phaidon, London

Leone De Castris P (2007) Simone Martini. Motta, Milan

Lewis S (1987) The art of Matthew Paris in the 'Chronica Maiora. University of California Press, Berkeley

Ling R (2003) Fresco and other forms of wall painting. In: Lindley P (ed) Making Medieval Art. Tyas, Donington, pp 4-29

Mady E, Chartier C, Prévot G, Vignaud C, Garay H (2006) The colour of ochres explained by their composition. Mater Sci Eng 127:70-80

Maltese C (ed) (2019) Le tecniche artistiche, 25th edn. Mursia, Milan

Mango C (1972) The art of the Byzantine Empire 312-1453. Sources and Documents. Toronto University Press, Toronto

Marabelli M, Santopadre P, Ioele M, Bianchetti PL, Castellano A, Cesareo R (2005a) La tecnica pittorica di Giotto nella Cappella degli Scrovegni: studio dei materiali. In: Basile G (ed) Giotto nella cappella Scrovegni: materiali per la tecnica pittorica. Studi e ricerche dell'Istituto Centrale per il Restauro. Bollettino d'Arte - Monographic issue, pp 17-46

Marabelli M, Santopadre P, Ioele M, Cesareo R, Castellano A, Verità M (2005b) Le lamine metalliche utilizzate nella decorazione dei dipinti murali giotteschi. In: Basile G (ed) Giotto nella cappella Scrovegni: materiali per la tecnica pittorica. Studi e ricerche dell'Istituto Centrale per il Restauro. Bollettino d'Arte - Volume speciale, pp 121-144

Mariani Canova G (1998) 'Duodecim celestia signa et septem planete cum suis proprietatibus': l'immagine astrologica nella cultura figurativa e nell'illustrazione libraria a Padova tra Trecento e Quattrocento. In: Spiazzi AM (ed) Il palazzo della Ragione di Padova. Indagini preliminari per il restauro, studi e ricerche. Canova, Treviso, pp 23-56

Mastrotheodoros GP, Beltsios KG, Bassiakos Y (2021) Pigments iron-based red, yellow and brown ochres. Archaeological and Anthropological Sciences (forthcoming)

Matteini M, Moles A (1990) Le tecniche di doratura nella pittura murale. In: Danti C, Matteini M, Moles A (eds) Le pitture murali: tecniche, problemi, conservazione. Centro Di, Florence, pp 121-126

Mayer R (1987) The artist's handbook of materials and techniques, 3rd edn. Faber and Faber, London

Meiss M (1967) French painting in the time of Jean de Berry. Phaidon, New York 
Merryfield MP (1999) Original treatises dating from the $12^{\text {th }}$ to $18^{\text {th }}$ centuries on the arts of painting, 3rd edn. Dover Publications, New York

Merzenich C (1996) Dorature e policromie delle parti architettoniche nelle tavole d'altare toscane del Trecento e Quattrocento. Kermes 26:51-71

Millidge S (2003) Cartoon. Grove Art Online. https://www.oxfor dartonline.com/groveart/view/10.1093/gao/9781884446054. 001.0001/oao-9781884446054-e-7000014487?rskey=SPjet $\mathrm{n} \&$ result $=1$. Accessed 30 Jan 2020

Mitchell J, Leal B (2013) In: De Marchi PM (2013) (ed) Castelseprio e Torba. Sintesi delle ricerche e aggiornamenti. SAP Società Archeologica, San Lorenzo, pp 315-348

Monciatti A (2002) Navata. Volte. Maestro di San Francesco. Motivi decorativi (1260 ca). In: Bonsanti G (ed) La Basilica di San Francesco ad Assisi, II. Franco Cosimo Panini, Modena, pp 342-343

Mora P, Mora L, Philippot P (1984) Conservation of wall paintings. Butterworths, London

Mora P, Mora L, Philippot P (1999) Technique et Conservation des peintures murals. Centre International d'Études pour la Conservation des Biens Culturels et Comité de l'Icom pour les Laboratoires de Musée, Washington

Mora P, Mora L, Philippot P (2001) La conservazione delle pitture murali, 2nd edn. Compositori, Bologna

Moretto LM, Orsega EF, Massocchin GA (2011) Spectroscopic methods for the analysis of celadonite and glauconite in Roman green wall paintings. Journal of Cultural Heritage 12(4):384-391

Müntz E (1889) Le pape Urbain V. Esssai sur l'histoire de l'art à Avignon. Revue Archéologique XIV:1-10

Müntz E (1890) Le Giottino a Rome. D'après des documents inédits. In: Les Archives des Arts. Recueil de documents inedits ou peu connu. Libraire de l'Art, Paris

Murat Z (2016) Guariento. Pittore di corte, maestro del naturale. Silvana Editoriale, Cinisello Balsamo

Murat, Z. (2021) Wall paintings through the ages. The medieval period (Italy, $12^{\text {th }}-15^{\text {th }}$ century). Archaeological and Anthropological Sciences. https://doi.org/10.1007/s12520-021-01410-4

Muratori LA (1739) Compositiones ad tingenda Musiva, Pelles, et alia, ad deaurandum ferrum, ad Mineralia, ad Chrysographiam, ad glutina quaedam conficienda, aliaque artium documenta, ante Annos nongentos scripta. In: Muratori L (ed) Antiquitates italicae medii aevi, 2, Mediolani, ex typographia Societatis Palatinae in Regia Curia, diss. xxiv, cols 365-388

Nicola M, Aceto M, Gheroldi V, Gobetto R, Chiari G (2018) Egyptian blue in the Castelseprio mural painting cycle. Imaging and evidence of a non-traditional manufacture. J Archeol Sci: Reports 19:465-475

Nimmo N, Olivetti C (1985-1986) Sulle tecniche di trasposizione dell'immagine in epoca medievale. RINASA 8-9:399-411

Osticioli I, Mendes NFC, Nevin A, Gil FP, Becucci M, Castellucci E (2009) Analysis of natural and artificial ultramarine blue pigments using laser induced breakdown and pulsed Raman spectroscopy, statistical analysis and light microscopy. Spectrochimica Acta. Part A, Molecular and Biomolecular Spectroscopy 73(3):525-531

Pagès i Paretas M (2017) Las pinturas de San Pedro de Arlanza en el contexto artístico de su época. In: Poza Yagüe M, Olivares Martínez D (eds) Alfonso VIII y Leonor de Inglaterra. Ediciones Complutense, Madrid, pp 175-200

Pérez-Arantegui J (2021) Not only wall paintings - Pigments for cosmetics. Archaeological and Anthropological Sciences. https:// doi.org/10.1007/s12520-021-01399-w

Pesenti FR (1997) 'Del modo di colorire le incarnationi e i vestiri' in Giotto, dopo alcuni restauri. In: Marconi S (ed) Scritti e immagini in onore di Corrado Maltese. Quasar, Rome, pp $149-157$

Piattoli R (1930) Un mercante del Trecento e gli artisti del suo tempo. Rivista d'arte, XII:97-150

Piola Casselli F (1981) La costruzione del Palazzo dei Papi a Avignone (1316-1367). Giuffrè, Milan

Piovesan et al (2012) = Piovesan R, Mazzoli C, Maritan L (2012) Fresco and lime-paint: an experimental study and objective criteria for distinguishing between these painting techniques. Archaeometry 54(4):723-736

Procacci U (1961) Sinopie e affreschi. Electa, Milan

Procacci U (1977) Disegni per esercitazione degli allievi e disegni preparatori per le opere d'arte nella testimonianza del Cennini. In: Lavin I, Plummer J (eds) Studies in late medieval and Renaissance painting in honor of Millard Meiss. New York University Press, New York, pp 352-467

Procacci U, Guarnieri L (1975) Come nasce un affresco. Bonechi, Florence

Raspe RE (1781) Critical essay on oil-painting, proving that the art of painting in oil was known before the pretended discovery of John Hubert Van Eyck; to which are added, Theophilus De arte pingendi, Eraclius De artibus Romanorum. Printed for the author by H. Goldney, and sold by T. Cadell, London

Recanati MG (2005) Il 'Taccuino' di Giovannino de' Grassi: un bestiario fantastico. FMR 8:107-132

Ricotta V (2019) Il 'Libro dell'arte' di Cennino Cennini: edizione critica e commento linguistico. Franco Angeli, Milan

Richards JC (1940) A new manuscript of Heraclius. Speculum $15: 255-271$

Rinaldi S (ed) (1998) Tecniche di pittura murale dall'alto Medioevo al Quattrocento. Lithos, Rome

Roehrig Kaufmann V (2003) Zackenstil. Grove Art Online. https:// www.oxfordartonline.com/groveart/view/10.1093/gao/97818 84446054.001.0001/oao-9781884446054-e-7000093138\#oao9781884446054-e-7000093138. Accessed 30 Jan 2020

Romano G (1963) Disegno. In: Previtali G (ed) Enciclopedia Feltrinelli Fischerm 22.2/I Arte. Feltrinelli, Milan

Roosen-Runge H (1967) Farbgebung und Technik frühmittelalterlicher Buchmalerei: Studien zu den Traktaten 'Mappae clavicula' und 'Heraclius', , vol 2. Deutscher Kunstverlag, Munich

Rutgers LV (2017) Painting: Fresco. In: Finney PC (ed) The Eerdmans encyclopedia of early Christian art and archaeology. William B. Eerdmans Publishing Company, Grand Rapids, pp $278-283$

Salvadori M, Sbrolli C (2021) Wall paintings through the ages. The Roman period: Republic and early Empire. Archaeological and Anthropological Sciences. https://doi.org/10.1007/ s12520-021-01411-3

Santner M (2012) The painting process in the Bishop's Chapel in Gurk, Carinthia (Austria). In: Eyb-Green S, Townsend J (eds) The artist's process. Technology and interpretation. Archetype, London, pp 193-194

Sapin C (ed) (1990) Saint-Germain d'Auxerre intellectuels et artistes dans l'Europe carolingienne IXe-XIe siècles. Auxerre, Musée d'Art et d'Histoire

Scheller RW (1963) A survey of medieval books. Bohn, Harlem

Scheller RW (1995) Exemplum: model-book drawings and the practice of artistic transmission in the Middle Ages (ca.900ca.1470). Amsterdam University Press, Amsterdam

Scirea F (2015) (ed) San Tommaso ad Acquanegra sul Chiese. Storia, architettura, contesto figurativo di una chiesa abbaziale romanica. SAP Società Archeologica, Mantova

Skovran A (1958) Introduction à l'histoire des manuels de peinture. Zbornik Zastite Spomenika Kulture 9:39-48 
Smith CS, Hawthorne JG (1974) Mappae clavicula: a little key to the world of medieval techniques. Trans Am Philos Soc 64(4):1-128

Soldano Tosatti B (1983) La 'Tabula de vocabulis sinonimis et equivocis colorum', ms. lat. 6741 della Bibliothèque Nationale di Parigi in relazione a Giovanni Alcherio. ACME - Annali Della Facoltà Di Lettere e Filosofia Dell'università Di Milano 36:129-187

Soldano Tosatti B (1991) Alcherio, Giovanni. In: Romanini AM (ed) Enciclopedia dell'Arte Medievale, vol I. Istituto della Enciclopedia Italiana, Rome, p 324

Solomon SD, Rutkowsky SA, Mahon ML, Halpern EM (2011) Synthesis of copper pigments, malachite and verdigris: making tempera paint. J Chem Educ 88(12):1694-1697

Speer A (ed) (2014) Zwischen Kunsthandwerk und Kunst: die 'Schedula diversarum artium.' Gruyter, Berlin

Spring M, Grout R (2002) The blackening of Vermilio: an analytical study of the process in paintings. National Gallery Technical Bulletin 23:50-61

Švarcová S, Hradil D, Hradilová J, Čermáková Z (2021) Pigments Copper-based greens and blues. Archaeological and Anthropological Sciences. https://doi.org/10.1007/s12520-021-01406-0

Thompson DV Jr (1933) Artificial vermilion in the Middle Ages. Technical Studies 2:62-70

Thorndike L (1959) Some medieval texts on colours. Ambix VII:1-24

Torresi AP (2004) (ed) Il libro dell'arte della pittura: Il manoscritto della Biblioteca nazionale centrale di Firenze, con integrazioni dal Codice riccardiano. Liberty House, Ferrara

Tosatti BS (1991) (ed) Il manoscritto veneziano. Un manuale di pittura e altre arti, miniatura, incisioni, vetri e vetrate e ceramiche- di medicina, farmacopea e alchimia del Quattrocento. Carma Acanthus Ed., Milan

Tosatti BS (1993) Cennini, Cennino di Drea. In: Romanini AM (ed) Enciclopedia dell'Arte Medievale, vol 4. Istituto della Enciclopedia Italiana, Rome, pp 612-613

Tosatti BS (2000) Teofilo. In: Romanini AM (ed) Enciclopedia dell'Arte Medievale, vol 9. Istituto della Enciclopedia Italiana, Rome, pp 129-131

Tosatti BS (2000) Trattati tecnico-artistici. In: Romanini AM (ed) Enciclopedia dell'Arte Medievale, vol 11. Istituto della Enciclopedia Italiana, Rome, pp 316-319

Tosatti BS (2007) Trattati medievali di tecniche artistiche. Jaca Book, Milan

Tosatti SB (2015) I dipinti murali: tecniche, procedure, materia pittorica. In: Scirea F (ed) San Tommaso ad Acquanegra sul Chiese Storia, architettura, contesto figurativo di una chiesa abbaziale romanica. SAP Società Archeologica, Mantova, pp 205-250
Travaini L (2005) Monete, battiloro e pittori. L'uso dell'oro nella pittura murale e i dati della cappella degli Scrovegni. In: Basile G (ed) Giotto nella cappella Scrovegni: materiali per la tecnica pittorica. Studi e ricerche dell'Istituto Centrale per il Restauro. Bollettino d'Arte - Monographic issue, pp 145-152

Uda M, Sassa S, Yoshimura Y, Kondo J, Nakamura M, Ban Y, Adachi $\mathrm{H}$ (2000) Yellow, red and blue pigments from ancient Egyptian palace painted walls. Nuclr Inst Methods Phys Res B 161(163):758-761

Urbani G (ed) (1978) Corso sulla manutenzione di dipinti murali, mosaici, stucchi. Tecniche d'esecuzione/Materiali costitutivi. Centro Stampa, Rome

Viñas SM (1998) Original written sources for the history of mediaeval painting techniques and materials: a list of published texts. Stud Conserv 43:114-124

Vitti P (2021) Mortars and masonry - Structural lime and gypsum mortars in Antiquity and Middle Ages. Archaeological and Anthropological Sciences. https://doi.org/10.1007/s12520-021-01408-y

Weitzmann K (1970) Illustrations in roll and codex: a study of the origin and method of text illustration. Princeton University Press, Princeton

Winter J (1983) The characterization of pigments based on caron. Stud Conserv 28:49-66

Wirth KA (2006) 'Pictor in Carmine'. Ein Handbuch Der Typologie Aus Der Zeit Um 1200, nach MS 300 des Corpus Christi College in Cambridge. Gebr. Mann, Berlin

Wirth J (2015) Villard de Honnecourt: architecte du XIII ${ }^{\mathrm{e}}$ siècle. Librairie Droz, Genève

Zanardi B, Arcangeli L, Apollonia L (1984) Della natura del bianco sangiovanni. Un pigmento e la lettura delle fonti. Ricerche Di Storia Dell'arte 24:63-74

Zanardi B (1995) Sul problema delle finiture a calce nella pittura medievale a fresco e i capitoli XV e XVI della 'Diversarum artium schedula' del monaco Teofilo. Sancta Sanctorum. Electa, Milan, pp 258-269

Zanardi B (1996) Il cantiere di Giotto. Le storie di san Francesco ad Assisi. Skira, Milan

Zanardi B (2002) Giotto e Pietro Cavallini. La questione di Assisi e il cantiere medievale della pittura a fresco. Skira, Milan

Publisher's Note Springer Nature remains neutral with regard to jurisdictional claims in published maps and institutional affiliations. 